\title{
Phenotypic assessment of safety and probiotic potential of native isolates from marine fish Moolgarda seheli towards sustainable aquaculture
}

\author{
Fazal Husain ${ }^{1}$ - Senbagam Duraisamy ${ }^{1}$ - Senthilkumar Balakrishnan ${ }^{2}$ · Sukumar Ranjith ${ }^{1}$. \\ Prahalathan Chidambaram ${ }^{3}$. Anbarasu Kumarasamy ${ }^{1}$
}

Received: 16 July 2021 / Accepted: 29 October 2021 / Published online: 10 January 2022

(c) Institute of Molecular Biology, Slovak Academy of Sciences 2022

\begin{abstract}
Aquaculture is a highly productive and fast-growing agricultural sector. The occurrence of epidemic or sporadic disease outbreak is a major limiting factor in this sector, thus better alternatives are the need of the hour. Use of indigenous probiotics is a promising strategy to control infectious diseases. Thus, the present study was aimed to screen and characterize potent indigenous probiotics from marine fish, Moolgarda seheli, towards enhancing sustainable aquaculture production. Totally 347 bacterial isolates were obtained from $M$. seheli gastrointestinal tract, out of these, four isolates (KAF121, 124, 135, 136) were confirmed as potent probiotics in terms of biosafety, highly resistant to acidic $\mathrm{pH}$, gastric juice, bile salt, high hydrophobicity to solvents, auto and co-aggregation potential. These four isolates also exhibited virtuous antioxidant activity. Further the isolates, KAF124 and 135 proved their efficiency in growth and survival of fish after challenged againt Aeromonas hydrophila. The isolates were identified based on their 16S rRNA gene sequence and the data were submitted to Genbank as Pseudomonas aeruginosa KAF121 (MH393516), Bacillus cereus KAF124 (MH393226), Bacillus thuringiensis KAF135 (MH393230), and Pseudomonas otitidis KAF136 (MH393230). The results conclude that two isolates, KAF124 and KAF135 are highly safe and potent probiotics which are first time isolated from the marine fish M. seheli. The two Bacillus strains could be used as better alternatives to antibiotics and other chemical-based drugs to prevent/control infectious diseases in aquaculture.
\end{abstract}

Keywords Aquaculture · Probiotics · Gastrointestinal tract · Antioxidant activity · Bacillus cereus

\section{Abbreviations \\ GI Gastrointestinal tract \\ CMFRI Central marine fisheries research institute \\ MTCC Microbial type culture collection centre \\ BHI agar Brain heart infusion agar \\ CFU Colony forming ability}

Fazal Husain and Senbagam Duraisamy contributed equally to this work.

Anbarasu Kumarasamy

anbumbt@bdu.ac.in

1 Microbial Biotechnology Laboratory, Department of Marine Biotechnology, Bharathidasan University, Tiruchirappalli, Tamil Nadu 620 024, India

2 Department of Medical and Molecular Microbiology, Microtech Laboratories, Attur, Tamil Nadu 636 102, India

3 Department of Biochemistry, Bharathidasan University, Tiruchirappalli, Tamil Nadu 620 024, India

$\begin{array}{ll}\text { BSH } & \text { Bile salt hydrolase } \\ \text { DPPH } & \text { 2, 2-diphenyl-1-picryl-hydrazyl } \\ \text { ABTS } & \text { 2-Azinobis-(3-ethylbenzothiazoline-6-sulfonic } \\ & \text { acid) di-ammonium salt } \\ \text { TSA } & \text { Tryptic soy agar } \\ \text { CMC } & \text { Carboxymethyl cellulose } \\ \text { TSA } & \text { Tryptic soy agar } \\ \text { PCR } & \text { Polymerase chain reaction } \\ \text { RBC } & \text { Red blood cell } \\ \text { WBC } & \text { White blood cell } \\ \text { HGB } & \text { Hemoglobin } \\ \text { HCT } & \text { Hematocrit } \\ \text { MCV } & \text { Mean corpuscular volume } \\ \text { MCH } & \text { Mean corpuscular hemoglobin } \\ \text { MCHC } & \text { Mean corpuscular hemoglobin concentration } \\ \text { EDTA } & \text { Ethylenediamine tetraacetic acid } \\ \text { BLASTn } & \text { Basic local alignment search tool for } \\ & \text { nucleotide } \\ \text { NCBI } & \text { National centre for biotechnology information }\end{array}$




\section{Introduction}

Aquaculture has become a promising food sector to sustain the global demand for nutritional and protein-rich diet to the continuously rising human population. The consumption of fish and fish products is rapidly increasing in both developed and developing countries due to high-quality protein content and existence of essential nutrients such as vitamins, minerals, polyunsaturated fatty acids, etc. India follows China in contributing $6.3 \%$ of global fish production (Mo et al. 2018). Nevertheless, the growth of aquaculture industries is hampered by unpredictable mass mortalities due to sudden infectious disease outbreaks (Hai 2015). The worldwide economic loss due to disease outbreaks in aquaculture industries has been estimated as more than US $\$ 6.0$ billion per annum (Vijayan et al. 2017). Patil et al. (2021) reported that probability of disease outbreaks in India was about $49 \%$ with 0.21 million ton shrimp lost per annum including the cost of US 1.02 billion. Most of the disease outbreaks are caused by bacterial pathogens belonging to Edwardsiella, Pseudomonas, Aeromonas, Vibrio, and Streptococcus (Anbarasu et al. 1998; Austin 2015; Austin and Austin 2012).

Conventional approaches like the usage of chemotherapeutics and chemical additives have a significant role in treating infectious diseases (NewajFyzul et al. 2014) during aquaculture pond preparation and rearing conditions. However, their extensive and indiscriminate use has led to harmful consequences like the development of multi-drug resistance, accumulation of antibiotic residues in aquatic habitats and in fish muscles (Bachere 2000), besides causing alteration in the microbiota of aquatic environments (de Azevedo et al. 2015) and food web. Vaccination and immunostimulant supplementation are proved as the best measures to prevent microbial diseases. However, due to various management difficulties and cost-effectiveness their usage remains very limited in aquaculture industries especially in South Asia (Anbarasu and Chandran 2001; Loh 2017). Hence, the development of alternative strategies to control infectious diseases has been a foremost alarm nowadays in order to improve aquaculture production.

Similarly, probiotics have also been identified as a better alternative to combat a wide range of infectious agents including bacteria, fungi, parasitic and viral pathogens. The application of probiotics in aquaculture is not only limited to gastrointestinal diseases/disorders, it is also involved in the overall health of the host organisms via acting as a growth promoter (Gobi et al. 2018), decreasing feed conversion ratio (Hoseinifar et al. 2017), preventing microbial diseases (Meidong et al. 2018), enhancing the innate immunity (Chauhan and Singh 2019) and improving water quality (Ma et al. 2009; Kolndadacha et al. 2011). They are known to act both as prophylactic and therapeutic agents either via competitive exclusion of specific target pathogens or directly inhibiting their adherence, survival, and colonization non-specifically (Meena et al. 2014; Newaj-Fyzul et al. 2014).

Indigenous probiotics are more advantageous than any other origins in terms of their ability to adhere and to colonize the intestinal wall of the host. Feeding habits and trophic levels of fish are the major influencing factors that determine the gut microflora ( $\mathrm{Li}$ et al. 2016). Probiotics have been characterized from the gut of freshwater fish such as Osphronemus goramy (Ghosh et al. 2007), Oreochromis niloticus (Lara-Flores and Olvera-Novoa 2013; Putar 2015), Channa striatus (Allameh et al. 2014), Catla catla (Muthukumar and Kandeepan 2015), Labeo rohita (Thankappan et al. 2015), and the digestive tract of shrimp - Litopenaeus vannamei (Widanarni et al. 2015) and molluscs - Anadara tuberculosa (Sanchez et al. 2015). However, only limited studies revealed the significance and characterization of marine probiotics (Wanka et al. 2018). In fact, there is an increasing demand for native probiotics since others could cause many immunological complications. In this pipeline, the present study was designed to isolate and characterize their probiotics attributes towards managing disease outbreaks in mariculture.

\section{Materials and methods}

\section{Sampling}

The marine fish, Moolgarda seheli ( $>25 \mathrm{~g}$ ) were collected from the Bay of Bengal, India $\left(10.7672^{\circ} \mathrm{N}, 79.8449^{\circ} \mathrm{E}\right)$, and transported to the laboratory by keeping in an icebox for further processing.

\section{Indicator pathogens and positive control probiotic}

Antimicrobial potential of marine fish bacterial isolates was evaluated against common fish pathogens such as Aeromonas hydrophila, Vibrio alginolyticus, Vibrio parahaemolyticus and Staphylococcus aureus were obtained from Central Marine Fisheries Research Institute (CMFRI), Mandapam, Tamil Nadu, India, and other strains, Shigella flexneri MTCC 1457, Enterococcus. faecalis MTCC 439, A. hydrophila MTCC 1739, Escherichia coli MTCC 40, Pseudomonas aeruginosa MTCC 4679, S. aureus MTCC 737, Klebsiella pneumoniae MTCC 39 and Proteus vulgaris MTCC 426 were purchased from Microbial Type Culture Collection (MTCC), Chandigarh, India. 
The Bacillus subtilis culture was purified from the commercially available fish probiotic product and confirmed by morphological and biochemical characterization. A single colony of purified B. subtilis was cultured and used as positive control.

\section{Screening of bacterial isolates}

The marine fish $M$. seheli gastrointestinal tract was excised, crushed, and serially diluted in peptone water (1\%). The sample was inoculated on nutrient agar and brain heart infusion (BHI) agar plates and incubated at $37{ }^{\circ} \mathrm{C}$ for $24 \mathrm{~h}$. Based on the colony morphology, discrete colonies were randomly selected and sub-cultured 3-4 times to get the pure culture of each isolate. The isolates were preliminarily identified by Gram's staining, endospore staining, and motility test, besides screening for their probiotic's attributes.

At the outset, the well-grown bacterial isolates were checked for their antimicrobial activity against fish pathogens and MTCC strains intended for screening purposes as described by Nandi et al. (2017). Shortly, Muller Hinton agar plates were swabbed evenly with $50 \mu \mathrm{L}$ of a logarithmic broth culture of the above-mentioned indicators containing $2.3 \times 10^{8} \mathrm{CFU} / \mathrm{mL}$. After $5 \mathrm{~min}$, wells of $8 \mathrm{~mm}$ were cut, $25 \mu \mathrm{L}$ of a log phase probiotics culture containing $1.6 \times 10^{8} \mathrm{CFU} / \mathrm{mL}$ was loaded onto the wells and incubated at $37^{\circ} \mathrm{C}$ for $12-14 \mathrm{~h}$. The zone of inhibition was measured in diameter and recorded.

\section{Preliminary biosafety assessment (production of hemolysin, gelatinase, lipase, and profiling of antibiotic sensitivity)}

The isolates showing antimicrobial activity were further evaluated for their biosafety by assessing the virulence factors such as hemolytic activity, gelatin liquefaction, lipase production, and antibiotic sensitivity. All the tests were performed at different incubation temperatures and time to check the presence of virulence factors, as detailed in the following three different trials.

The hemolytic activity of the selected isolates was checked using nutrient agar enriched with human blood $(5 \%)$. After $48 \mathrm{~h}$ of incubation, the plates were observed for a clear zone around the growth ( $\beta$-type hemolysis), irregular or partial and greenish zone ( $\alpha$ - type hemolysis), and no zone or reaction ( $\gamma$-hemolysis).

Gelatinase production was tested by following Perin et al. (2014) with minor modifications. Shortly, nutrient agar plates supplemented with $3 \%$ gelatin $(\mathrm{w} / \mathrm{v})$ was spotted with $3 \mu \mathrm{L}$ of bacterial isolates $\left(1.8 \times 10^{7} \mathrm{CFU} / \mathrm{mL}\right)$ and incubated at different temperatures such as $37^{\circ} \mathrm{C}$ for 2 days, $25^{\circ} \mathrm{C}$ for 3 days and $4{ }^{\circ} \mathrm{C}$ for 10 days to observe a clear halo zone around the colony.
Lipase production was assessed by spotting $3 \mu \mathrm{L}$ culture of bacterial strains $\left(2.4 \times 10^{7} \mathrm{CFU} / \mathrm{mL}\right)$ on the surface of nutrient agar enriched with $1 \%(\mathrm{v} / \mathrm{v})$ of tween 80 and $0.2 \%(\mathrm{w} / \mathrm{v})$ of calcium chloride, incubated at different temperatures such as $37{ }^{\circ} \mathrm{C}$ for 2 days, $25{ }^{\circ} \mathrm{C}$ for 3 days and $4{ }^{\circ} \mathrm{C}$ for 10 days. The clear halo zone observed around the colony indicates positive for lipase production.

The bacterial isolates were checked for their antibiotic sensitivity against the following antibiotics by disc diffusion assay: chloramphenicol $(25 \mu \mathrm{g})$, tobramycin $(10 \mu \mathrm{g})$, erythromycin $(15 \mu \mathrm{g})$, streptomycin $(10 \mu \mathrm{g})$, tetracycline $(10 \mu \mathrm{g})$, methicillin $(10 \mu \mathrm{g})$, ampicillin $(10 \mu \mathrm{g})$, cetoxim $(30 \mu \mathrm{g})$, ciprofloxacin $(10 \mu \mathrm{g})$, vancomycin $(10 \mu \mathrm{g})$, trimethoprim $(5 \mu \mathrm{g})$, sulfamethoxazole $(10 \mu \mathrm{g})$, norfloxacin $(10 \mu \mathrm{g})$, rifampicin $(5 \mu \mathrm{g})$ and amikacin $(30 \mu \mathrm{g})$. The disc of each antibiotic was placed on the surface of the Muller Hinton agar plate swabbed with $25 \mu \mathrm{L}$ of logarithmic phase culture $\left(2.8 \times 10^{7} \mathrm{CFU} / \mathrm{mL}\right)$. The antibiotic sensitivity/ resistance pattern was measured by the zone of inhibition following CLSI 2017 guidelines.

\section{Probiotic characterization}

\section{Tolerance to $\mathrm{pH}$, bile salt (sodium cholate) and simulated gastric juice}

The $\mathrm{pH}$ tolerance of the isolates was performed under acidic conditions according to the method of Jang et al. (2018) with minor modifications. Briefly, $1 \%$ of logarithmic phase bacterial cultures $\left(1.6 \times 10^{7} \mathrm{CFU} / \mathrm{mL}\right)$ with $0.5 \mathrm{OD}$ at $595 \mathrm{~nm}$ was inoculated into the nutrient broth adjusted to various $\mathrm{pH}$ such as 1.0, 2.0, 3.0 and 7.0, and incubated at $37^{\circ} \mathrm{C}$ in different time points such as $30,60,120$ and $180 \mathrm{~min}$ by measuring the OD at $595 \mathrm{~nm}$.

Bile salt tolerance was assessed in vitro to mimic the ability of the isolates survival in the small intestine. About $1 \%$ of the logarithmic phase culture containing $0.5 \mathrm{OD}$ at $595 \mathrm{~nm}$ was inoculated into the nutrient broth supplemented with 0.3 and $1 \%(\mathrm{w} / \mathrm{v})$ sodium cholate and incubated at $37{ }^{\circ} \mathrm{C}$. Survival was measured by checking OD at $595 \mathrm{~nm}$ after 30 , 60,120 and $180 \mathrm{~min}$. Nutrient broth containing $0 \%$ sodium cholate was served as control.

Simulated gastric juice tolerance of the bacterial isolates was assessed to determine the ability of the bacteria to survive in acidic and gastric juices in the fish stomach. The logarithmic phase culture $(1 \%)$ with 0.5 at OD $595 \mathrm{~nm}$ was inoculated into the nutrient broth supplemented with pepsin $(0.3 \%)$ and $\mathrm{NaCl}_{2}(0.5 \%)$, at $\mathrm{pH} 2$ and 3. Absorbance was recorded at $595 \mathrm{~nm}$ after incubating 30,60, 120 and $180 \mathrm{~min}$. Nutrient broth without any supplementation at $\mathrm{pH} 7$ was considered as a control. 
The survival rate was determined as follows:

Survival rate $\%=\frac{A 0}{A 1} \times 100$

where A1: Absorbance of control, A0: Absorbance of sample.

\section{Bile salt hydrolase activity}

The bacterial isolates bile salt hydrolase (BSH) activity was checked as described by Jayashree et al. (2014). Briefly, bile salt agar plates were supplemented with sodium cholate $(0.3 \%)$ and $\mathrm{CaCl}_{2}(0.375 \mathrm{~g} / \mathrm{L})$. About $8 \mathrm{~mm}$ wells were cut and $50 \mu \mathrm{L}$ of the broth culture $\left(1.8 \times 10^{7} \mathrm{CFU} / \mathrm{mL}\right)$ was loaded, and incubated at $37{ }^{\circ} \mathrm{C}$ for $72 \mathrm{~h}$. The formation of opaque granular white precipitate around the well was considered as positive.

\section{Cell surface hydrophobicity, auto aggregation and co-aggregation with pathogens}

The modified method of Rosenberg et al. (1980) was used to assess bacterial adhesion to various solvents. Briefly, logarithmic phase bacterial culture containing $1.5 \times 10^{7} \mathrm{CFU} /$ $\mathrm{mL}$ was centrifuged at $4000 \mathrm{rpm}$, washed twice in sterile PBS and resuspended in PBS. About $3 \mathrm{~mL}$ of cell suspension was transferred to 3 separate fresh tubes and $1 \mathrm{~mL}$ of ethyl acetate (monopolar; basic solvent), xylene (nonpolar; neutral) and chloroform (monopolar; acidic) were separately added. This mixture was then vortexed for 2 min followed by incubation at $37^{\circ} \mathrm{C}$ until two distinct layers were formed (@ $2 \mathrm{~h}$ ). The clear liquid was carefully pipetted out into fresh tubes and absorbance was measured at $595 \mathrm{~nm}$. The percentage of cell adherence was calculated by the following formula (Darlimaz et al. 2012; Valeriano et al. 2014)

Hydrophobicity\% $=((A 0-A 1) / A 0) \times 100$

where $\mathrm{A} 0$ is the absorbance of suspension before incubation and $\mathrm{A} 1$ is the absorbance of suspension after incubation.

Auto aggregation of the bacterial isolates was determined according to the method described by Darilmaz et al. (2012). Briefly, $18 \mathrm{~h}$ bacterial cultures were pelleted by centrifugation at $4000 \mathrm{rpm}$ for $10 \mathrm{~min}$, washed twice with PBS and re-suspended in PBS to get absorbance of 0.5 at $595 \mathrm{~nm}$. The suspension was centrifuged and the pellet was resuspended in an equal volume of PBS. After 1 and $2 \mathrm{~h}$ incubation, aggregation was determined by measuring the absorbance of upper clear suspension at $595 \mathrm{~nm}$ and the percentage was calculated as follows (Darlimaz et al. 2012):

Auto aggregation $\%=(1-A 1 / A 0) \times 100$ where $\mathrm{A}_{1}=$ absorbance of upper aqueous phase; $\mathrm{A}_{0}=$ absorbance of the control.

Similarly, co-aggregation was performed by following Zárate et al. 2002with minor changes. Shortly, bacterial culture suspensions were prepared as mentioned in the auto aggregation study. Equal quantity of isolated bacterial suspension and pathogenic bacteria (A. hydrophila, V. alginolyticus and S. aureus) were vortexed and incubated at $37^{\circ} \mathrm{C}$ as alone and mixture. The absorbance $\left(\mathrm{OD}_{595}\right)$ was recorded after 1 and $2 \mathrm{~h}$ incubation. The percentage of co-aggregation was calculated by the following formula

$\%$ of Co-aggregation $=\left[(A 1+A 2)-\frac{2(\text { Amix })}{A 1+A 2} \times 100\right]$

where A1: Absorbance at1h incubation, A2: Absorbance at $2 \mathrm{~h}$ incubation, A mix: Absorbance of culture added with probiotic and pathogen.

\section{Antioxidant assay}

The first three methods given below were followed by Jang et al. (2018) with minor modifications to determine the antioxidant activity of the bacterial isolates.

\section{2, 2-diphenyl-1-picryl-hydrazyl (DPPH) radical scavenging activity}

About $125 \mu \mathrm{L}$ of the bacterial isolates $\left(1.3 \times 10^{7} \mathrm{CFU} / \mathrm{mL}\right)$ was mixed with $120 \mu \mathrm{L}$ of $400 \mu \mathrm{M}$ DPPH solution as described by Das and Goyal (2015). The mixture was vortexed and incubated at $37{ }^{\circ} \mathrm{C}$ for $30 \mathrm{~min}$ in dark condition. The absorbance was measured at $517 \mathrm{~nm}$ and the percentage of scavenging DPPH radicals was calculated using the following formula:

DPPH radical scavenging activity $\%=\left[1-\frac{\text { Absorbance of sample }}{\text { Absorbance of control }}\right] \times 100$

\section{2-Azinobis-(3-ethylbenzothiazoline-6-sulfonic acid) di-ammonium salt (ABTS) radical scavenging activity}

The $\mathrm{ABTS}^{+}$solution was produced by mixing $14 \mathrm{mM}$ ABTS in water with $5 \mathrm{mM}$ potassium persulfate in the dark at room temperature for $16 \mathrm{~h}$. The $\mathrm{ABTS}^{+}$solution was diluted with distilled water until it reached an absorbance of 0.7 at $734 \mathrm{~nm}$. $150 \mu \mathrm{L}$ of the bacterial isolates $\left(1.3 \times 10^{7} \mathrm{CFU} / \mathrm{mL}\right)$ was added into an equal amount of $\mathrm{ABTS}^{+}$solution, vortexed for $1 \mathrm{~min}$ and incubated at $37^{\circ} \mathrm{C}$ for $10 \mathrm{~min}$. The absorbance was read at $734 \mathrm{~nm}$. The percentage of ABTS radical scavenging activity was calculated as follows: 
ABTS radical scavenging activity\%

$=\left(1-\frac{\text { Absorbance ofsample }- \text { Absorbance of blank }}{\text { Absorbance of control }}\right) \times 100$

\section{$\beta$ - carotene bleaching inhibitory activity}

About $2 \mathrm{mg}$ of $\beta$-carotene was dissolved in $44 \mu \mathrm{L}$ of linoleic acid and $0.2 \mathrm{~mL}$ of tween $80 \mathrm{in} 10 \mathrm{~mL}$ of chloroform. The mixture was thoroughly vortexed and allowed to stand until chloroform was fully evaporated and immediately diluted to $100 \mathrm{~mL}$ with distilled water. About $4.5 \mathrm{~mL}$ emulsion was mixed with $0.5 \mathrm{~mL}$ bacterial isolates $\left(1.3 \times 10^{7} \mathrm{CFU} / \mathrm{mL}\right)$, vortexed and incubated in a water bath at $50{ }^{\circ} \mathrm{C}$ for $2 \mathrm{~h}$. The absorbance of the emulsion was recorded at $470 \mathrm{~nm}$ and the remaining $\beta$-carotene in the mixture was calculated according to the following formula:

$\beta-$ Carotene bleaching inhibitory activity\%

$=\frac{\text { Absorbance of sample, } 2 h-\text { Absorbance of control, } 2 h}{\text { Absorbance of sample, } 0 h-\text { Absorbance of control, } 0 h} \times 100$

\section{Reducing power}

The assay was carried out according to Das and Goyal (2015). Bacterial isolates $\left(200 \mu \mathrm{L}\right.$ containing $1.3 \times 10^{7} \mathrm{CFU} /$ $\mathrm{mL}$ ) was mixed with $0.2 \mathrm{~mL}$ of $0.2 \mathrm{M}$ sodium phosphate buffer ( $\mathrm{pH}$ 6.6) with $0.2 \mathrm{~mL}$ of $1 \%$ potassium ferricyanide, and incubated at $50{ }^{\circ} \mathrm{C}$ for $20 \mathrm{~min}$. Then, $0.2 \mathrm{~mL}$ of $10 \%$ trichloroacetic acid was added and centrifuged at $7000 \mathrm{rpm}$ for $10 \mathrm{~min}$. About $0.5 \mathrm{~mL}$ of an upper layer was mixed with $0.1 \mathrm{~mL}$ of $0.1 \%$ ferric chloride and $0.4 \mathrm{~mL}$ of distilled water, reacted for $10 \mathrm{~min}$ and its absorbance was measured at $700 \mathrm{~nm}$ using a spectrophotometer. L-Cysteine was used as a control standard.

\section{Proteolytic, amylolytic and cellulolytic activity of the bacterial isolates}

These in vitro experiments were conducted to check the ability of bacterial isolates to hydrolyze proteins, carbohydrates, and cellulose as described by Thankappan et al. (2015) with minor modifications. Briefly, $2 \mu \mathrm{L}$ of $18 \mathrm{~h}$ old broth culture was spotted on the surface of tryptic soy agar (TSA) supplemented with $2 \%$ skimmed milk powder for proteolysis, $2 \%$ starch for amylolysis and $1 \%$ carboxymethyl cellulose (CMC) for the cellulolytic activity. After incubation at $37^{\circ} \mathrm{C}$ for $48 \mathrm{~h}$, the plates were observed for a clear halo zone around the colony for proteolysis, after being flooded with Lugol's iodine solution for amylolytic and with $1 \%$ potassium iodide solution for cellulolytic activity.

\section{Determination of probiotics efficiency in fish survival and blood parameters}

Based on the above probiotic characterization, the KAF124 and 135 were selected for evaluating their impact on fish survival and blood parameters.

\section{Experimental diet}

To check the efficiency of probiotics, 4 groups in triplicates each containing 20 fish (L. rohita) of $10.8 \pm 1.0 \mathrm{~g}$, were separately maintained in 4 fish tanks with constant aeration. The basal fish feed was given to all fish during acclimatization. The first and second group was fed with fish feed supplemented with KAF124 and KAF135 respectively $\left(2.2 \times 10^{8} \mathrm{CFU} / \mathrm{g}\right)$. The third group was fed with a fish diet supplemented with commercial B. subtilis $\left(2.4 \times 10^{8} \mathrm{CFU} / \mathrm{g}\right)$ and the fourth group was given a diet without any bacterial supplementation (control). The fish from all the groups were fed with a diet at $5 \%$ of the body weight and the fish weight was measured for every week and the feed ratio was changed accordingly. The survival rate was recorded till 30 days. Fish body weight gain was estimated as the difference between the initial weight and end of the experiment.

\section{Hematological and biochemical parameters analysis}

Fish were randomly chosen from all the above groups. Then they were immersed in water added with $0.1 \mathrm{ppm}$ tricaine methane sulfonate in order to anesthetize before collecting blood. About $500 \mu \mathrm{L}$ of blood was collected via heart puncture using one mL syringe with $5 \mu \mathrm{L}$ of $10 \%$ EDTA solution to count of red blood cells (RBC), and white blood cells (WBC), and to determine the level of haemoglobin (HGB), haematocrit (HCT), mean corpuscular volume (MCV), mean corpuscular haemoglobin (MHC) and mean corpuscular haemoglobin concentration (MCHC). All these parameters were analysed as described by Tachibana et al. (2020).

Furthermore $500 \mu \mathrm{L}$ of blood was collected and centrifuged to separate serum. The serum was used to analyse serum protein, albumin, globulin and blood glucose using fully automated chemistry analyser, Erba EM 200 (Transasia Bio-medicals Ltd., India).

\section{Challenge test against $A$. hydrophila}

Challenge test was conducted, in duplicate, for all the four groups treated as mentioned in the probiotic diet experiment. 
All the four groups of fish (20 Nos.) were divided into two subgroups (each containing 10 Nos.) and infected via feed as given earlier $A$. hydrophila containing $2.2 \times 10^{8} \mathrm{CFU} /$ $\mathrm{mL}$ and PBS (pH 7) as control. All the infected fish were observed for 10 days and survival rate was recorded.

\section{Phenotypic characterization of the probiotics isolates}

The selected probiotics were identified by morphological characterization viz; Gram's staining, endospore staining and motility test and biochemical analysis viz; production of indole, acid, alkalene, $\mathrm{H}_{2} \mathrm{~S}$, oxidase, catalase, urease, nitrite from nitrate and utilization of citrate. Carbohydrate fermentation tests using sugars such as sucrose, lactose, mannitol, glucose, maltose, fructose, xylose, rhamnose, sorbitol and cellulose were also carried out to characterize the isolates.

\section{Molecular characterization of isolates}

Genomic DNA of the all four fish origin bacterial isolates showing safety characteristics was extracted by the phenolchloroform method and confirmed in $1 \%$ agarose gel.

\section{Gene sequencing (16S rRNA) and phylogenetic analysis}

The 16S rRNA gene was amplified by universal primers, 27F (5'-AGAGTTTGATGMTGGCTCAG-3'), and 1492R (5'- GGTTACCTTGTTACGACTT-3') at the following PCR conditions: Initial denaturation at $94{ }^{\circ} \mathrm{C}$ for $5 \mathrm{~min}$ followed by 34 cycles of $94{ }^{\circ} \mathrm{C}$ for $1 \mathrm{~min}$ (denaturation), $55^{\circ} \mathrm{C}$ for $1 \mathrm{~min}$ (annealing) and $72{ }^{\circ} \mathrm{C}$ for $3 \mathrm{~min}$ (extension), and a final extension at $72{ }^{\circ} \mathrm{C}$ for $7 \mathrm{~min}$ and cooled at $4{ }^{\circ} \mathrm{C}$. The amplified products were extracted using the QIA-quick PCR extraction kit (QIAGEN) and sequenced. The sequences were analyzed using BLASTn and aligned against reference sequences using CLUSTAL W. Rooted phylogenetic trees based on the 16S rRNA gene sequences were constructed using the neighbor-joining method in MEGA X (Kumar et al. 2018), combined with bootstrap analysis. The sequences were submitted to NCBI GenBank.

\section{Statistical analysis}

All the experiments in this study were conducted in triplicates and analyzed by the one-way variance of analysis and Student's 't' test using Graph pad Prism 6. The data were given as mean $\pm \mathrm{SD}$ of triplicates. The significance was analysed at $P<0.05, \mathrm{P}<0.01, P<0.001$.

\section{Results}

\section{Antimicrobial screening}

A total of 347 distinct bacterial isolates were collected from the gastrointestinal tract of healthy marine fish Moolgarda seheli. The pure culture of all the isolates was stored in 5\% glycerol at $-80^{\circ} \mathrm{C}$ for further characterization. Well grown 121 isolates were checked for their antimicrobial screening against 4 fish pathogens and 8 MTCC strains including both Gram-positive and negative bacteria as mentioned earlier. Amongst these, 26 isolates showed antagonistic activity against all the bacterial pathogens tested $(100 \%$ activity) including Gram-negatives such as $V$. alginolyticus, $A$. hydrophila, V. parahaemolyticus, S. flexneri 1457, E. coli 40, A. hydrophila 1739, P. aeruginosa 4679, K. pneumoniae 39, P. vulgaris 426 and Gram positives such as $S$. aureus, Enterococcus faecalis 439 and S. aureus 737. Similarly, 44 strains showed $66 \%$ antimicrobial activity, another 18 strains showed $25 \%$ activity and the remaining 33 isolates didn't inhibit ( $0 \%$ activity) any pathogen tested by agar well diffusion assay (Fig. 1).

\section{Biosafety assay}

The isolates showing efficient (100\%) antimicrobial activity (26/121) was considered as effective and further underwent various biosafety experiments such as hemolytic activity, gelatin liquefaction and lipase production. In the hemolytic activity, only the isolates KAF121, 124, 135 \& 136 were not produced in any type of zone around their colonies on blood agar plates. All the remaining isolates were not considered for further characterization as they showed $\alpha$ - type of hemolysis (Table 1).

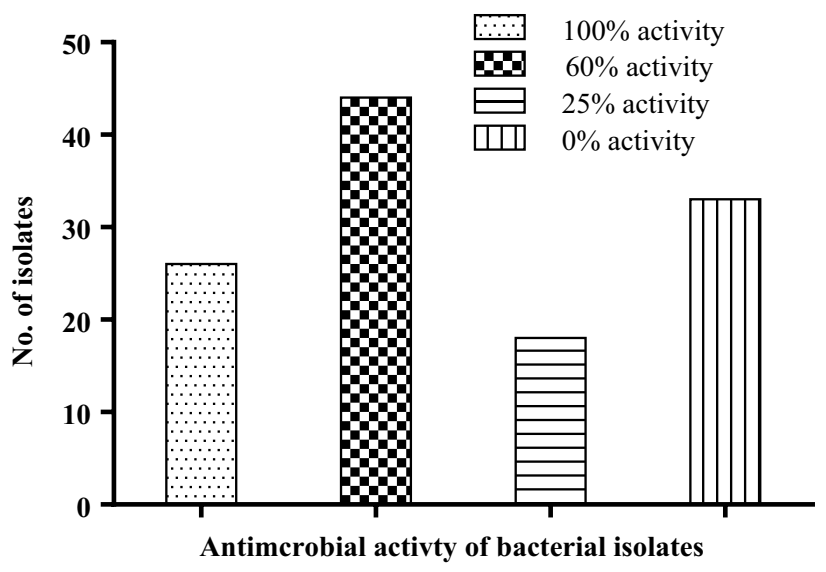

Fig. 1 Profiling of bacteria isolated from Moolgarda seheli based on their antimicrobial spectrum 
Table 1 Biosafety assessment of bacteria isolated from Moolgarda seheli towards screening of potent probiotics

\begin{tabular}{|c|c|c|c|c|c|c|c|c|}
\hline \multirow[t]{4}{*}{ Bacterial Isolates } & \multicolumn{8}{|l|}{ Phenotypes } \\
\hline & \multicolumn{7}{|l|}{ Activities } & \multirow[t]{3}{*}{ Antibiotic resistance } \\
\hline & \multirow[t]{2}{*}{ Haemolysin } & \multicolumn{3}{|c|}{ Gelatinase } & \multicolumn{3}{|l|}{ Lipase } & \\
\hline & & $\begin{array}{l}4{ }^{\circ} \mathrm{C} \\
10 \text { days }\end{array}$ & $\begin{array}{l}25^{\circ} \mathrm{C} / \\
3 \text { days }\end{array}$ & $\begin{array}{l}37^{\circ} \mathrm{C} / \\
2 \text { days }\end{array}$ & $\begin{array}{l}4{ }^{\circ} \mathrm{C} / \\
10 \text { days }\end{array}$ & $\begin{array}{l}25^{\circ} \mathrm{C} / \\
3 \text { days }\end{array}$ & $\begin{array}{l}37^{\circ} \mathrm{C} / \\
2 \text { days }\end{array}$ & \\
\hline KAF009 & $\alpha$ & + & + & + & + & + & + & Chl, Ery, Str, Amp, Met, Van, Ami \\
\hline KAF040 & $\alpha$ & + & + & + & + & + & + & Ery, Str, Amp, Met, Van \\
\hline KAF110 & $\alpha$ & + & + & + & + & + & + & Ery, Str, Amp, Met, Van \\
\hline KAF119 & $\alpha$ & + & + & + & + & + & + & Ery, Str, Amp, Met, Van \\
\hline KAF121 & $\gamma$ & - & - & - & - & - & - & Amp, Met \\
\hline KAF122 & $\alpha$ & + & + & + & + & + & + & Chl, Ery, Str, Amp, Met, Van, Ami \\
\hline KAF124 & $\gamma$ & - & - & - & - & - & - & Amp, Met \\
\hline KAF126 & $\alpha$ & + & + & + & + & + & + & Ery, Str, Amp, Met, Van, Ami \\
\hline KAF128 & $\alpha$ & + & + & + & + & + & + & Amp, Met \\
\hline KAF131 & $\alpha$ & + & + & + & + & + & + & Ery, Str, Amp, Met, Rif \\
\hline KAF134 & $\alpha$ & + & + & + & + & + & + & Ery, Str, Amp, Met, Van, Rif \\
\hline KAF135 & $\gamma$ & - & - & - & - & - & - & Amp, Met \\
\hline KAF136 & $\gamma$ & - & - & - & - & - & - & Amp, Met \\
\hline KAF139 & $\alpha$ & + & + & + & + & + & + & Ery, Str, Amp, Met, Rif \\
\hline KAF141 & $\alpha$ & + & + & + & + & + & + & Amp, Met \\
\hline KAF142 & $\alpha$ & + & + & + & + & + & + & Ery, Str, Amp, Met, Van, Rif \\
\hline KAF167 & $\alpha$ & + & + & + & + & + & + & Ery, Str, Amp, Met, Rif \\
\hline KAF190 & $\alpha$ & + & + & + & + & + & + & Chl, Ery, Str, Amp, Met, Rif \\
\hline KAF204 & $\alpha$ & + & + & + & + & + & + & Ery, Str, Amp, Met, Rif \\
\hline KAF208 & $\alpha$ & + & + & + & + & + & + & Chl, Str, Amp, Met, Rif \\
\hline KAF209 & $\alpha$ & + & + & + & + & + & + & Chl, Str, Amp, Met, Rif \\
\hline KAF213 & $\alpha$ & + & + & + & + & + & + & Str, Amp, Met, Rif, Sxt,Amk \\
\hline KAF217 & $\alpha$ & + & + & + & + & + & + & Chl, Str, Amp, Met, Rif \\
\hline KAF222 & $\alpha$ & + & + & + & + & + & + & Chl, Str, Amp, Met \\
\hline KAF239 & $\alpha$ & + & + & + & + & + & + & Ery, Str, Amp, Met, Rif \\
\hline KAF247 & $\alpha$ & + & + & + & + & + & + & Chl, Str, Amp, Met \\
\hline
\end{tabular}

Similarly, among the 26 isolates, 22 produced a clear halo zone around their colonies in gelatin liquefaction and lipase production assays. Moreover, these isolates showed positive results at all incubation temperatures $\left(4,25\right.$ and $\left.37^{\circ} \mathrm{C}\right)$. The remaining four isolates (KAF121, 124, $135 \&$ 136) were negative for gelatin liquefaction and lipase production at all the tested conditions (Table 1).

For antibiotic sensitivity assay, the isolates such as KAF121, 124, 128, 135, 136 and 141 were resistant to methicillin and ampicillin, and highly sensitive to all other remaining antibiotics tested viz; chloramphenicol, tobramycin, erythromycin, streptomycin, tetracycline, cetoxim, ciprofloxacin, vancomycin, trimethoprim, sulfamethoxazole, norfloxacin, rifampicin and amikacin (Table 1). Based on the above results, the four isolates namely, KAF121, 124, 135 and 136 were successfully proved their biosafety facets and their probiotic attributes were assessed.

\section{Effect of acidic $\mathrm{pH}$, gastric juice and bile salt concentration}

For the acid tolerance assay, a gradual reduction in survival rate was observed after $30 \mathrm{~min}$ at all $\mathrm{pH}(1-3)$ in relation to increased incubation time. Nevertheless, all the four isolates survived after $180 \mathrm{~min}$, in specific to the isolate KAF124 showed the highest percentage of survivability $(61,67 \& 70 \%)$ at $\mathrm{pH} 1,2$ and 3 respectively, followed by KAF135, 121, 136, and $B$. subtilis detailed results were shown in Table 2.

Similarly, in bile salt tolerance in vitro assay results illustrate that $B$. subtilis showed the highest survival of 70 and $58 \%$ after $180 \mathrm{~min}$ incubation at 0.3 and $1 \%$ of sodium cholate respectively and followed by KAF124 and 135 with marginal difference. (Table 2). 
Table 2 Potential probiotic isolates viability in acidic, bile salt and gastric juice exposure at different time points in various $\mathrm{pH}$ and bile salt concentration

\begin{tabular}{|c|c|c|c|c|c|c|c|c|}
\hline \multirow[t]{2}{*}{ Bacterial isolates } & \multirow[t]{2}{*}{$\begin{array}{l}\text { Time points } \\
(\mathrm{min})\end{array}$} & \multicolumn{3}{|c|}{ Survival (\%) at low $\mathrm{pH}$} & \multicolumn{2}{|c|}{ Survival (\%) at bile condition } & \multicolumn{2}{|c|}{$\begin{array}{l}\text { Survival (\%) at simulated } \\
\text { gastric juice }\end{array}$} \\
\hline & & $\mathrm{pH} 1$ & $\mathrm{pH} 2$ & $\mathrm{pH} 3$ & $0.3 \%$ & $1 \%$ & $\mathrm{pH} 2$ & pH 3 \\
\hline \multirow[t]{4}{*}{ KAF121 } & 30 & $66 \pm 1.3^{*}$ & $74 \pm 2.4^{* *}$ & $76 \pm 3.4^{\#}$ & $70 \pm 1.5^{* * *}$ & $65 \pm 1.3^{* *}$ & $70 \pm 1.5^{* * *}$ & $74 \pm 2.3^{\#}$ \\
\hline & 60 & $61 \pm 2^{\#}$ & $71 \pm 3.1^{* *}$ & $73 \pm 3.3^{*}$ & $67 \pm 1.5^{* * *}$ & $57 \pm 1.5^{* * *}$ & $69 \pm 2.3^{* * *}$ & $70 \pm 1.3^{* *}$ \\
\hline & 120 & $57 \pm 2.3^{\#}$ & $64 \pm 3.3^{* *}$ & $67 \pm 1.7^{*}$ & $62 \pm 1.1^{* * * *}$ & $50 \pm 2.3^{\#}$ & $57 \pm 2.0^{\#}$ & $62 \pm 2.2^{* *}$ \\
\hline & 180 & $54 \pm 1.5^{* * *}$ & $56 \pm 4.1^{\#}$ & $61 \pm 2.0^{* * * *}$ & $57 \pm 1.5^{* * *}$ & $45 \pm 2.3^{*}$ & $50 \pm 1.1^{* * *}$ & $54 \pm 1.8^{* *}$ \\
\hline \multirow[t]{4}{*}{ KAF124 } & 30 & $70 \pm 2.0^{* * * *}$ & $75 \pm 3.4^{* *}$ & $77 \pm 3.1^{*}$ & $75 \pm 2.4^{\#}$ & $70 \pm 1.4^{*}$ & $68 \pm 1.5^{* * *}$ & $72 \pm 1.3^{\#}$ \\
\hline & 60 & $67 \pm 3.1^{* * *}$ & $72 \pm 1.3^{* * *}$ & $75 \pm 2.0^{* * *}$ & $74 \pm 1.5^{\#}$ & $63 \pm 2.2^{\#}$ & $65 \pm 2.0^{* * * *}$ & $70 \pm 1.0^{* *}$ \\
\hline & 120 & $64 \pm 3.3^{* * *}$ & $70 \pm 3.1^{* * * *}$ & $72 \pm 3.4^{\#}$ & $71 \pm 1.3^{* *}$ & $62 \pm 2.1^{* *}$ & $62 \pm 2.3^{* *}$ & $67 \pm 1.5^{* * *}$ \\
\hline & 180 & $61 \pm 1.3^{* *}$ & $67 \pm 2.7^{* * *}$ & $70 \pm 1.3^{* * *}$ & $68 \pm 1.4^{\#}$ & $50 \pm 2.3^{\#}$ & $59 \pm 1.5^{* * *}$ & $65 \pm 2.0^{* *}$ \\
\hline \multirow[t]{4}{*}{ KAF135 } & 30 & $68 \pm 2.5^{* *}$ & $74 \pm 3.4^{*}$ & $75 \pm 2.5^{\#}$ & $73 \pm 1.3^{\#}$ & $68 \pm 2.2^{\#}$ & $67 \pm 1.3^{* * * *}$ & $73 \pm 1.5^{\#}$ \\
\hline & 60 & $65 \pm 3.4^{* *}$ & $70 \pm 3.2^{* *}$ & $71 \pm 1.5^{\#}$ & $71 \pm 1.5^{*}$ & $60 \pm 1.5^{*}$ & $64 \pm 2.3^{* *}$ & $71 \pm 1.3^{* *}$ \\
\hline & 120 & $63 \pm 2.0^{* * * *}$ & $67 \pm 1.6^{* *}$ & $70 \pm 1.7^{\#}$ & $68 \pm 2.0^{\#}$ & $55 \pm 2.4^{*}$ & $61 \pm 2.0^{* *}$ & $65 \pm 2.0^{*}$ \\
\hline & 180 & $59 \pm 3.3^{* * *}$ & $65 \pm 2.5^{* * *}$ & $67 \pm 2.0^{\#}$ & $63 \pm 1.5^{* *}$ & $50 \pm 1.1^{\#}$ & $58 \pm 1.3^{* * * *}$ & $63 \pm 2.0^{*}$ \\
\hline \multirow[t]{4}{*}{ KAF136 } & 30 & $71 \pm 1.3^{* * *}$ & $74 \pm 1.1^{*}$ & $76 \pm 3.3^{\#}$ & $68 \pm 2.7^{* * * *}$ & $66 \pm 1.5^{\#}$ & $70 \pm 1.3^{\text {**** }}$ & $72 \pm 1.5^{\#}$ \\
\hline & 60 & $58 \pm 3.1^{\#}$ & $70 \pm 3.3^{* *}$ & $71 \pm 1.5^{\#}$ & $64 \pm 2.4^{* * *}$ & $55 \pm 2.0^{* * *}$ & $61 \pm 2.3^{\#}$ & $65 \pm 1.3^{*}$ \\
\hline & 120 & $54 \pm 1.4^{\#}$ & $66 \pm 3.1^{* * *}$ & $68 \pm 3.1^{\#}$ & $58 \pm 1.3^{* * *}$ & $48 \pm 2.3^{* * *}$ & $57 \pm 3.0^{\#}$ & $61 \pm 2.3^{*}$ \\
\hline & 180 & $50 \pm 2.0^{\#}$ & $62 \pm 1.3^{* * *}$ & $65 \pm 2.0^{\#}$ & $50 \pm 1.5^{* * *}$ & $41 \pm 1.3^{* * *}$ & $51 \pm 1.3^{* *}$ & $56 \pm 2.0^{\#}$ \\
\hline \multirow[t]{4}{*}{ Positive control } & 30 & $64 \pm 1.7$ & $70 \pm 2.5$ & $74 \pm 2.4$ & $74 \pm 1.1$ & $68 \pm 2.3$ & $64 \pm 1.1$ & $72 \pm 3.1$ \\
\hline & 60 & $60 \pm 1.3$ & $64 \pm 3.4$ & $70 \pm 1.1$ & $73 \pm 1.5$ & $62 \pm 1.7$ & $60 \pm 1.7$ & $67 \pm 2.1$ \\
\hline & 120 & $56 \pm 3.4$ & $59 \pm 1.4$ & $70 \pm 3.1$ & $70 \pm 2.0$ & $58 \pm 2.0$ & $57 \pm 2.5$ & $63 \pm 1.3$ \\
\hline & 180 & $49 \pm 2.0$ & $56 \pm 1.0$ & $66 \pm 1.5$ & $67 \pm 3.1$ & $49 \pm 2.7$ & $53 \pm 1.1$ & $59 \pm 3.1$ \\
\hline
\end{tabular}

Values are given as mean \pm SD. Asterisks indicate the significant difference from commercial probiotic (positive control) and test probiotics (KAF $121,124,135 \& 136) .{ }^{*} P<0.05,{ }^{* *} P<0.01,{ }^{* * *} P<0.001$, \#: nonsignificant

Table 2 also depicts the simulated gastric juice tolerance rate of isolates at $\mathrm{pH} 2$ and 3 . The KAF124 exhibited the highest tolerance rate of 59 and $65 \%$ at $\mathrm{pH} 2$ and 3 respectively when compared to the other 3 isolates and commercial probiotics (KAF121, 135, 136 and B. subtilis) after $180 \mathrm{~min}$ of incubation. Likewise, the KAF121 showed the least tolerance rate of 50 and $54 \%$ at $\mathrm{pH} 2$ and 3 respectively after $180 \mathrm{~min}$.

All the four isolates possessed the BSH activity but the precipitation zone was significantly $(\mathrm{p}<0.5)$ varied among the isolates. KAF124 produced the largest precipitation zone (7.2 mm) followed by KAF135 and B. subtilis with $6.8 \mathrm{~mm}$. The other two isolates (KAF121 and 136) produced low BSH activity by producing less than $2.0 \mathrm{~mm}$ zone around the wells.

\section{Bacterial adherence to solvents}

The bacterial adherence activity in the gastrointestinal tract was evaluated under in vitro condition by their hydrophobicity to various solvents. It was denoted by high adherence to xylene (apolar solvent) and ethyl acetate (polar and basic). KAF135 showed a higher hydrophobicity to xylene $(76.9 \pm 2.3 \%)$ and ethyl acetate $(67.8 \pm 3.42 \%)$ than chloroform $(24.3 \pm 2.7 \%)$. Similarly, KAF124 also showed better hydrophobicity with xylene $(71.5 \pm 1.3 \%)$ and ethyl

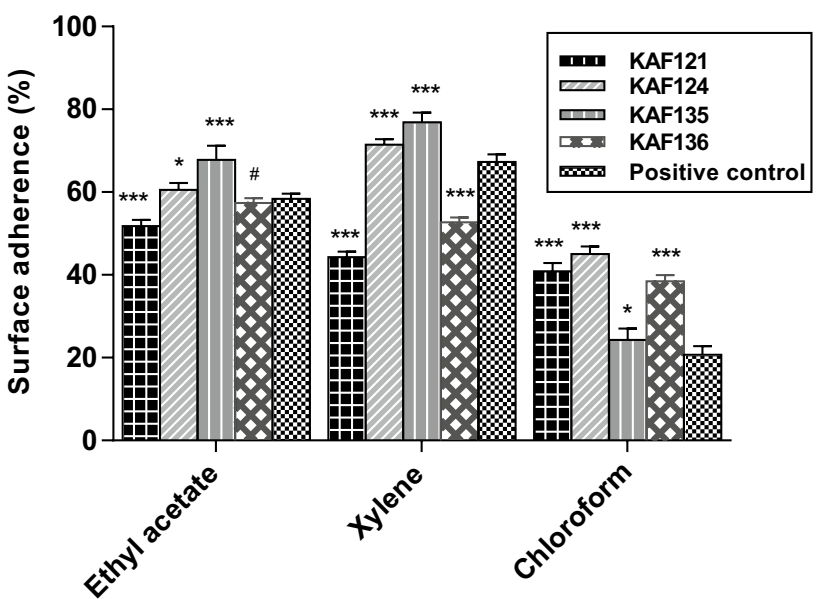

Fig. 2 Adhesion of bacterial isolates to various hydrocarbons after $1 \mathrm{~h}$ incubation. Values shown as mean $\pm \mathrm{SD}$. Asterisks indicate significant differences from positive control and test probiotics (KAF121, $124,135 \& 136) .{ }^{*} P<0.05,{ }^{* * *} P<0.001$, \#: nonsignificant 
acetate $(60.5 \pm 1.7 \%)$ than chloroform $(46 \pm 1.8 \%)$. But, KAF12 1 and 136 showed a higher percentage of hydrophobicity towards ethyl acetate than xylene. There was a significant difference $(P<0.05)$ was observed between test probiotics and B. subtilis (Fig. 2).

\section{Auto and co-aggregation}

The auto-aggregation result shows that all the four isolates showed good aggregation potential. KAF135 $(75.3 \pm 2.2 \%)$, $124(71.1 \pm 2.0 \%)$, KAF $136(61.7 \pm 1.8 \%)$ showed higher aggregation potential than the positive control, B. subtilis $(59.5 \pm 1.5 \%)$. While KAF121 showed least aggregation $(58.5 \pm 2.4 \%)$ with marginal difference at $2 \mathrm{~h}$ incubation (Fig. 3). Similarly, the co-aggregation property of the bacterial isolates was analyzed at $37^{\circ} \mathrm{C}$ using 3 different fish pathogens. All the strains tested showed good aggregation ability with all three pathogens but the percentage of aggregation significantly varied $(P<0.05)$ from each pathogen. The highest co-aggregation percentage was observed in KAF135 with $V$. alginolyticus $(32.6 \pm 2.2 \%)$, S. aureus $(29.6 \pm 2.0 \%)$ and A. hydrophila $(26.1 \pm 1.8 \%)$ than $B$. subtilis. Likewise, the least co-aggregation was observed from KAF136 with V. alginolyticus $(5.4 \pm 1.8 \%)$, S. aureus $(10.1 \pm 2.0 \%)$ and $A$. hydrophila $(13.7 \pm 2.2 \%)$ (Fig. 4).

\section{Antioxidant assay}

The antioxidant activity of bacterial isolates was determined by four different methods and the results are shown in Fig. 5. All the isolates were found to be possessing high

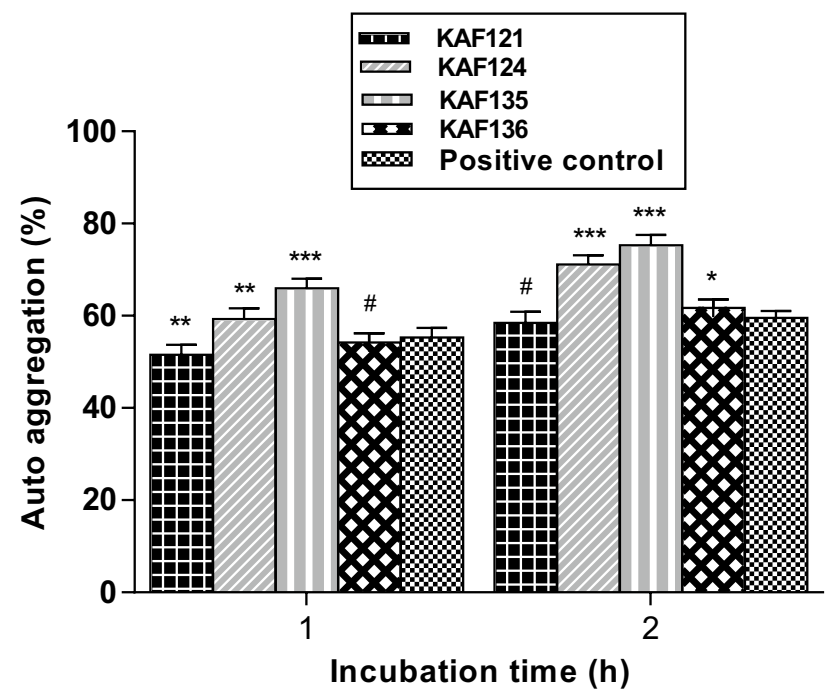

Fig. 3 Auto aggregation potential of bacterial isolates after incubation of 1 and $2 \mathrm{~h}$. Values represented as mean \pm SD of triplicates and asterisks indicate significant difference from positive control and test probiotics (KAF121, 124, $135 \& 136) .{ }^{*} P<0.05,{ }^{* *} P<0.01$, ${ }^{* * * *} P<0.001, \#$ : nonsignifant

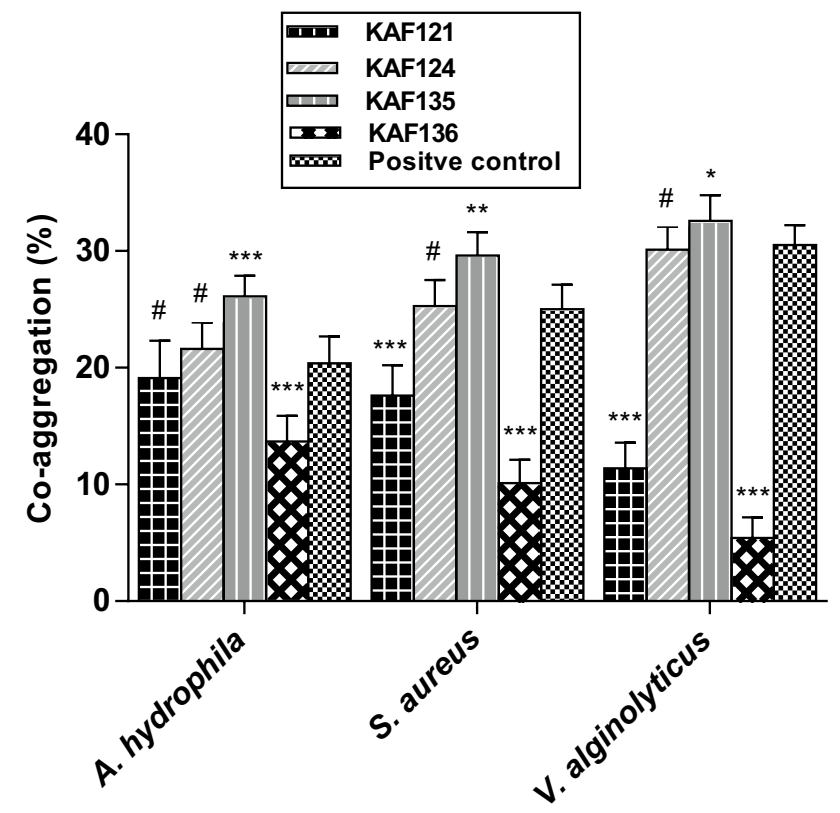

Fig. 4 Co-aggregation potential of bacterial isolates with fish pathogens (Aeromonas hydrophila, Staphylococcus aureus \& Vibrio alginolyticus) after $2 \mathrm{~h}$ incubation. Values are given as mean $\pm \mathrm{SD}$ of three replicates. Asterisks indicate significant differences from positive control and test probiotics (KAF121, 124, $135 \& 136) .{ }^{*} P<0.05$, ${ }^{* *} P<0.01,{ }^{* * *} P<0.001$, \#: nonsignificant

antioxidant activity. The isolate, KAF135 showed a high potential of scavenging DPPH $(93.3 \pm 3.4 \%)$, followed by B. subtilis $(87 \pm 2.7 \%)$, KAF124 with $83 \pm 3.0 \%$. For the ABTS method, all the four tested isolates exhibited the ability to scavenge the radical ABTS with a range of inhibitory percentage from 61.4 to $52.8 \pm 2.4 \%$. Among the isolates, KAF135 showed maximum activity $(61.4 \pm 1.5 \%)$ and KAF136 showed the least activity (52.8\%). The inhibitory activity of $\beta$-carotene bleaching results are highly promising and KAF135 (95.1\%) showed the maximum than all other isolates, KAF121 (56.1 $\pm 2.3 \%), 124(65.3 \pm 2.1 \%)$, B. subtilis $(60.4 \pm 2.1 \%)$ and $136(58.5 \pm 2.2 \%)$. According to the reducing power, the positive control, B. subtilis $(60.3 \pm 2.5 \mu \mathrm{M})$ showed the highest reducing power ability than the isolates, KAF121, 124, 135 and 136.

\section{Characterization of probiotics for extracellular enzymes}

The ability of isolates to produce various extracellular enzymes including protease, amylase and cellulase were checked by the plate assay method. All the four isolates and B. subtilis were found to be positive for protease, amylase and cellulose as a clear zone was observed around the colony in skim milk agar, starch agar and CMC respectively. 
Fig. 5 Antioxidant activity of bacterial isolates determined by different methods: (a) DPPH radical scavenging activity, (b) ABTS radical scavenging activity, (c) $\beta$ carotene bleaching inhibitory activity, (d) Reducing power. Values are given as mean \pm SD of three replicates. Asterisks indicate significant differences from positive control and test probiotics (KAF121, $124,135 \& 136) .{ }^{*} P<0.05$, ${ }^{* * *} P<0.01,{ }^{* * *} P<0.001$, \#: nonsignificant
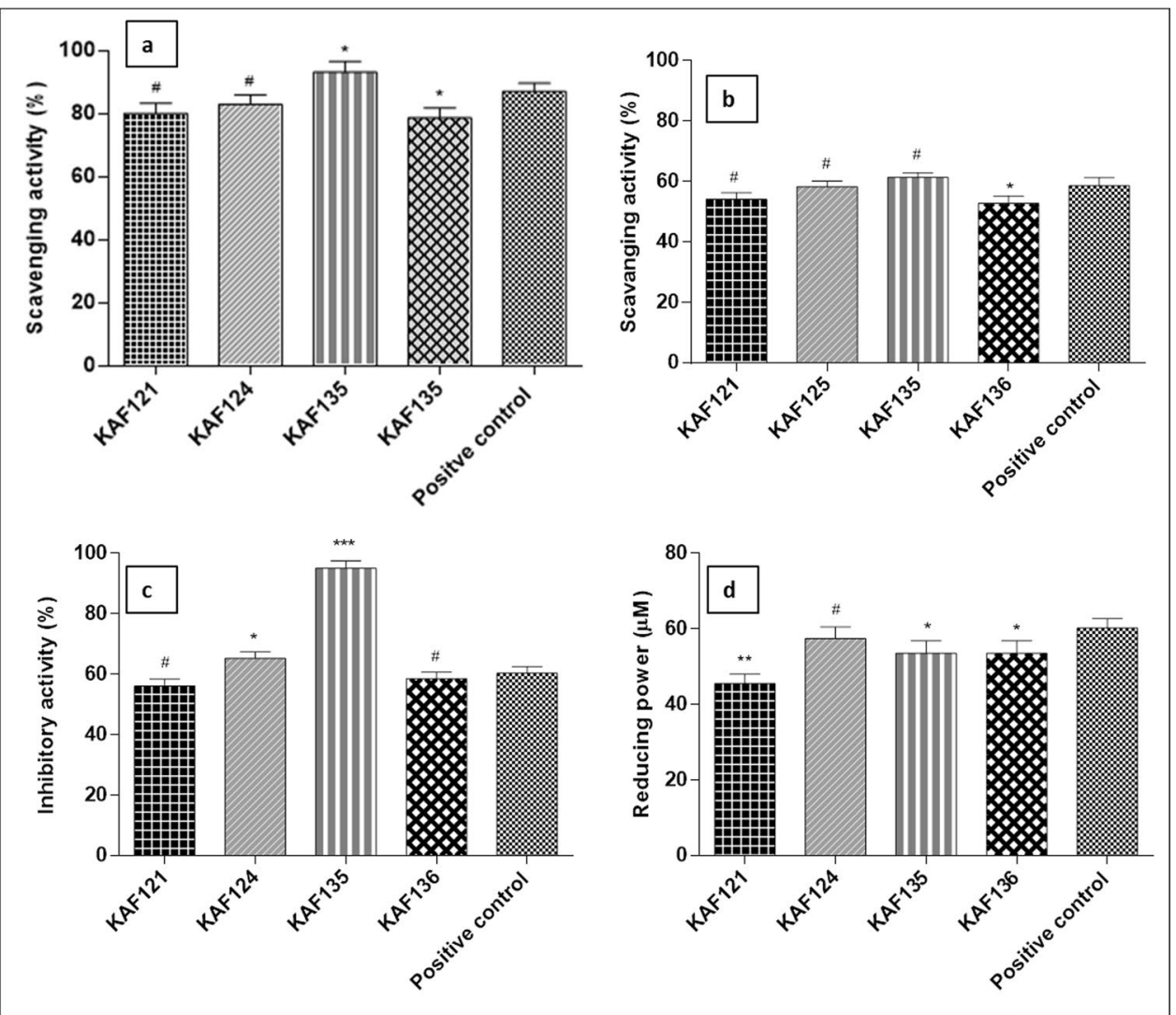

\section{Characterization of probiotics by challenge test}

There was no mortality observed when the fish were fed with KAF124, 135, B. subtilis and control group; perhaps a notable weight gain of 23.84, 23.13, 22.14 and 11.12 were observed respectively after 30 days of the experiment.

Blood was collected at the end of the experiment (30th day) from fish fed with KAF124, 135, B. subtilis and basal diet only (control). Overall results revealed the significant difference $(\mathrm{P}<0.05)$ between probiotics supplemented feed and basal feed given fish. Among the four groups, maximum WBC count was recorded from KAF124 supplemented fish $\left(350 \pm 3.46 \times 10^{6} / \mu \mathrm{L}\right)$, followed by KAF135 $\left(300 \pm 3.33 \times 10^{6} /\right.$ $\mu \mathrm{L})$ and $B$. subtilis $\left(280 \pm 4.24 \times 10^{6} / \mu \mathrm{L}\right)$. The results for the remaining parameters (RBC, $\mathrm{HCT}, \mathrm{MCV}, \mathrm{MCH}, \mathrm{MCHC}$ ) followed in the same hierarchy. However, maximum HGB was recorded from KAF135 added tank $(17.8 \pm 0.94 \mathrm{~g} / \mathrm{dL})$ and was followed by commercial probiotic (B. subtilis) $(16.7 \pm 1.23 \mathrm{~g} /$ $\mathrm{dL})$ and KAF124 $(15.1 \pm 0.78 \mathrm{~g} / \mathrm{dL})$ supplemented tanks with marginal difference (Table 3).

According to serum biochemical parameters, highest serum protein concentration was estimated from fish fed with diet mixed KAF124, $135(10.4 \pm 1.49,10.11 .13 \mathrm{~g} / \mathrm{dL}$ respectively) and commercial probiotic $(8.8 \pm 1.04 \mathrm{~g} / \mathrm{dL})$ than the control $(5.2 \pm 0.53 \mathrm{~g} / \mathrm{dL})$. Likewise, albumin level was also higher in probiotic supplemented groups (4.4-4.6 g/
dL) than control group $(2 \pm 0.58 \mathrm{~g} / \mathrm{dL})$. High serum globulin was observed from KAF124 supplemented fish $(5.9 \pm 0.63 \mathrm{~g} /$ $\mathrm{dL})$, followed by KAF135 $(4.2 \pm 0.84 \mathrm{~g} / \mathrm{dL})$ and $B$. subtilis $(4.0 \pm 0.56 \mathrm{~g} / \mathrm{dL})($ Table 3$)$.

The survival percentage was higher in KAF124 supplemented fish after challenging with A. hydrophila and there were no mortalities observed on the 10th day of the experiment. In the KAF135 supplemented fish group, 100\% survival was observed till the 7th day and it was reduced to $80 \%$ on the 10th day. The same survival rate was observed from the fish group given the commercial B. subtilis diet. Whereas in the control group, only $40 \%$ of survival was observed on the 7 th day and it was suddenly reduced to 10 and $0 \%$ on the consequent days.

\section{Identification of potent probiotics}

The isolates were primarily characterized by their phenotypic features such as morphological, physiological and carbohydrate fermentation patterns and compared with Bergey's Manual of Systematic Bacteriology. The genomic DNA was extracted, purified and amplified for their $16 \mathrm{~S}$ rRNA sequences and confirmed their presence by showing $1.5 \mathrm{~kb}$ in $1.2 \%$ agarose gel electrophoresis. The BLASTn analysis of 16S rRNA gene sequences of KAF121, 124, 135 and 136 showed that $98.3,100,97.4$ and $98 \%$ similarity 
Table 3 Effect of probiotics supplemented diet on blood and serum parameters of Labeo rohita (30 days experiment)

\begin{tabular}{|c|c|c|c|c|}
\hline Parameters & $\begin{array}{l}\text { KAF124 supple- } \\
\text { mented group }\end{array}$ & $\begin{array}{l}\text { KAF135 supple- } \\
\text { mented group }\end{array}$ & $\begin{array}{l}\text { Commercial probiotic sup- } \\
\text { plemented group }\end{array}$ & $\begin{array}{l}\text { Control fed } \\
\text { with basal } \\
\text { diet }\end{array}$ \\
\hline \multicolumn{5}{|l|}{ Hematological } \\
\hline $\mathrm{RBC}\left(\times 10^{6} / \mu \mathrm{L}\right)$ & $2.8 \pm 0.36^{* *}$ & $2.5 \pm 0.51^{*}$ & $2.4 \pm 0.42^{\#}$ & $1.8 \pm 0.12$ \\
\hline $\mathrm{WBC}\left(\times 10^{6} / \mu \mathrm{L}\right)$ & $350 \pm 3.46^{* * *}$ & $300 \pm 3.33^{* * *}$ & $280 \pm 4.24^{* * *}$ & $180 \pm 3.03$ \\
\hline Hemoglobin (HGB) (g/dL) & $15.1 \pm 0.78^{* * *}$ & $17.8 \pm 0.94^{* * *}$ & $16.7 \pm 1.23^{* * *}$ & $8.7 \pm 0.45$ \\
\hline Hematocrit (HCT) $(\%)$ & $40.2 \pm 1.43^{* * *}$ & $37.6 \pm 1.72^{* * * *}$ & $34.7 \pm 1.42^{* * *}$ & $20 \pm 2.49$ \\
\hline Mean corpuscular volume (MCV) (fL) & $245 \pm 3.14^{* * *}$ & $220 \pm 3.36^{* * *}$ & $232 \pm 4.63^{* * *}$ & $180 \pm 2.13$ \\
\hline Mean corpuscular hemoglobin $(\mathrm{MCH})(\mathrm{pg})$ & $118 \pm 2.40^{* * *}$ & $110 \pm 2.64^{* * * *}$ & $107.6 \pm 3.42^{* * *}$ & $70 \pm 2.26$ \\
\hline $\begin{array}{l}\text { Mean corpuscular haemoglobin concentration } \\
(\mathrm{MCHC})(\mathrm{g} / \mathrm{dL})\end{array}$ & $62.2 \pm 2.01^{* * * *}$ & $60.4 \pm 2.75^{* * * *}$ & $52.6 \pm 1.23^{* * *}$ & $35.8 \pm 2.31$ \\
\hline \multicolumn{5}{|l|}{ Biochemical } \\
\hline Serum protein $(\mathrm{g} / \mathrm{dL})$ & $10.4 \pm 1.49^{* * *}$ & $10.1 \pm 1.13^{* * * *}$ & $8.8 \pm 1.04^{* * *}$ & $5.2 \pm 0.53$ \\
\hline Serum Albumin (g/dL) & $4.6 \pm 0.86^{* * *}$ & $4.4 \pm 0.71^{* * *}$ & $4.4 \pm 0.4^{* * *}$ & $2 \pm 0.58$ \\
\hline Serum Globulin (g/dL) & $5.9 \pm 0.63^{* * *}$ & $4.2 \pm 0.84^{*}$ & $4.0 \pm 0.56^{\#}$ & $3 \pm 0.35$ \\
\hline Albumin/globulin ratio & $1.3 \pm 0.21^{* * *}$ & $1.1 \pm 0.08^{* * *}$ & $0.8 \pm 0.09^{* *}$ & $0.5 \pm 0.04$ \\
\hline Blood glucose $(\mathrm{mg} / 100 \mathrm{~mL})$ & $149.7 \pm 2.14^{* * * *}$ & $150.4 \pm 1.91^{* * *}$ & $137.5 \pm 1.36^{* * *}$ & $90 \pm 1.48$ \\
\hline
\end{tabular}

Values are given as mean \pm SD. Asterisks indicate the significant difference from control group and probiotics treated groups for 30 days of the experiment. ${ }^{*} P<0.05,{ }^{* *} P<0.01,{ }^{* * *} P<0.001$, \#: nonsignificant

with P. aeruginosa, B. cereus, Bacillus thuringiensis and Pseudomonas otitidis respectively. The sequences of $P$. aeruginosa KAF121, B. cereus KAF124 and B. thuringiensis KAF135 and $P$. otitidis KAF136 were submitted to NCBI and their accession numbers are MH393516, MH393226,
MH393230 and MH393232 respectively. The phylogenetic tree was constructed from the sequences with the sum of branch length for $P$. aeruginosa KAF121 (0.15), B. cereus KAF124 (0.00), B. thuringiensis KAF135 (0.01) and $P$. otitidis KAF136 (0.01) (Fig. 6).

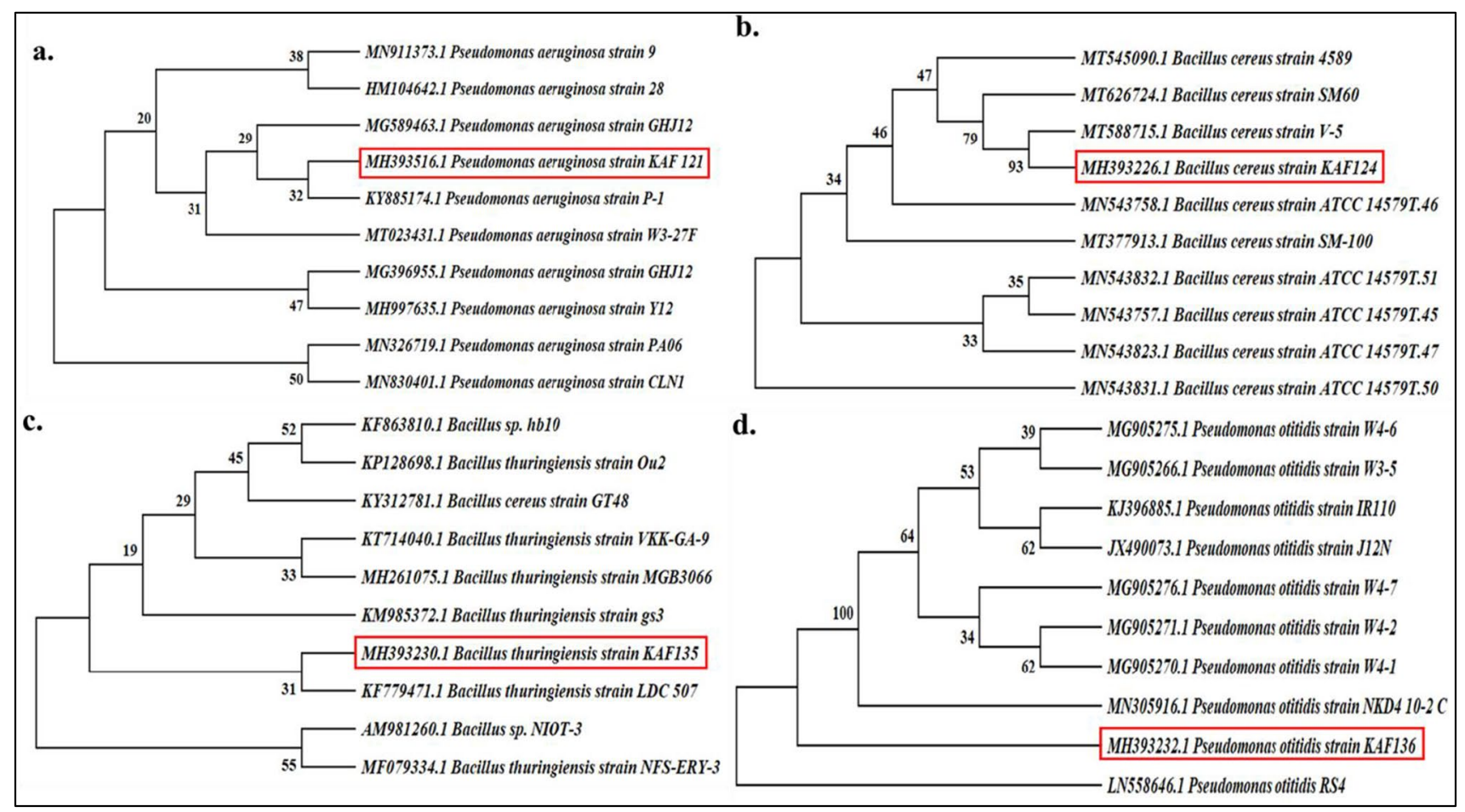

Fig. 6 Phylogenetic tree to analyse the evolutionary relationship of probiotic isolates (a) Pseudomonas aeruginosa KAF121, (b) Bacillus cereus KAF124, (c) Bacillus thuringiensis KAF135, (d) Pseudomonas otitidis KAF136 


\section{Discussion}

Mariculture is a highly fascinating and profitable agricultural sector, developed all over the coastal line, to meet sustainable aquaculture production. In India, the total fish production during the period of 2017-18 is around 12 million metric tons, in which $50 \%$ of the production is from culture fisheries (http://nfdb.gov.in/about-indian-fisheries. $\mathrm{html}$ ). Nevertheless, this industry is continuously facing many challenges including infectious disease outbreaks due to the emergence of drug-resistant pathogens, which leads to major loss to the industry in terms of heavy mortality, loss of food scarcity and economic crisis. To overcome this issue, scientifically proven advanced preventive, therapeutic and environmentally safe approaches are the need of the hour.

Fish gut consists of an unexplored and dynamic microbial ecosystem (Nayak 2010), besides which gut microbes are mirrors of the host's health status and potent defenders of infectious pathogens. In order to make use of these beneficial aspects of these unexplored gut microbes, it is indispensable to characterize them completely. Probiotics are living microbes when acquired adequately provide a number of benefits to the host by reshaping the gut microenvironment. Recent research findings illustrate that probiotics supplementation has the ability to prevent/control microbial infections including SARS-CoV-2 (Gohil et al. 2021). The majority of probiotics available in the market for aquaculture originated from terrestrial livestock (Martínez et al. 2012) which have not completely demonstrated their successful persistence and colonization in the fish gut. So, native probiotics must be identified and characterized, being considered for better adaptation to the fish gut microenvironment. At this point, the present study illustrates the marine fish, Moolgarda seheli GI microbe's characteristics towards identifying them as probiotics. Among the several isolated autochthonous bacterial communities, closely associated with the fish gut region, a few pathogenic strains also existed with antagonism towards aquatic pathogens including $A$. hydrophila, $V$. alginolyticus, Vibrio parahemolyticus, and S. aureus.

Earlier reports are evidence that several potential probiotics bacteria exhibiting antagonistic activity against a wide range of Gram-positive and negative pathogens (Thankappan et al. 2015). The Bacillus sp. identified as a potent probiotic has the ability to produce many pharmaceutically significant antibiotics ( $>150)$ against pathogens including Helicobacter pylori (Pinchuk et al. 2001) by its $4-5 \%$ of the genome (Stein 2005). In this study, we initially screened gut isolates with antagonistic activity against a wide range of pathogens. Among them, four bacterial isolates namely, KAF121, 124, $135 \& 136$ displayed the best results in terms of antagonistic activity and inhibited the growth of pathogens tested (A. hydrophila, V. alginolyticus, V. parahaemolyticus, S. aureus, S. flexneri MTCC 1457, E. faecalis MTCC 439, A. hydrophila MTCC 1739, E. coli MTCC 40, P. aeruginosa MTCC 4679, S. aureus MTCC 737, K. pneumoniae MTCC 39 and P. vulgaris MTCC 426) indicating their broad antimicrobial spectrum against fish and human pathogens.

Further, the presently isolated bacteria were both Gram positives (B. cereus KAF124, B. thuringiensis KAF135) and negatives (P. aeruginosa KAF121 and Pseudpmonas otitidis KAF136). Bacillus strains are industrially important bacteria with the ability to produce proteolytic enzymes (Urdaci and Pinchuk 2004; Jadhav et al. 2017) antioxidants (Shen et al. 2010) and tolerate extreme environmental conditions (Thankappan et al. 2015) due to their spore-forming ability. Various Bacillus sp. were evaluated for their efficacy in various sectors like poultry, cattle and aquaculture (Hong et al. 2005; Mazza 1994). However, Bacillus clausii was a potent probiotic commercially available in the market (Enterogermina) to balance the intestinal flora during diarrhea or antibiotic therapy (Thankappan et al. 2015). The existing activity of $P$. aeruginosa KAF121 and $P$. otitidis KAF136 were especially interesting since they are considered as opportunistic pathogens. The biosafety assay results confirm that they are non-pathogenic by means of not producing $\alpha-$, and $\beta$-hemolysins, negative for gelatin liquefaction and lipase production. In addition, earlier studies are proven that Pseudomonas can be used as probiotics in aquaculture (Hoque et al. 2019).

The antibiotic susceptibility profile revealed that the selected isolates are immune to methicillin and ampicillin while being susceptible to all other antibiotics tested. The sensitivity of the probiotics to certain commercial antibiotics is one of the requisites of probiotics. Antibiotic-resistant probiotics can transfer their genes to other gut microflora (Zheng et al. 2017) and are harmful to fish and humans, as secondary consumers via the food chain.

To exert the beneficial effect as probiotics on the host, the bacteria must have the ability to survive during the transition time between the stomach and upper part of the intestine, and sufficient numbers must be reached and colonized in the gut (Abatenh 2018). So, resistance to low pH in the in vitro assay is a positive phenomenon to overcome the host stomach gastric juice and bile salt in the small intestine, which is one of the significant selection criteria to identify as potent probiotics. All the selected isolates showed varying viability levels in low $\mathrm{pH}$. The highest survival rate was observed in B. cereus (68 and 57\% in 0.3 and $1 \%$ of bile salt respectively) when compared to other bacteria. This result is concurrent with reports of Thankappan et al. (2015) who observed the highest tolerance of $B$. subtilis in $0.3 \%$ than at $1 \%$ bile salt. The physiological concentration of bile salt in 
the fish gut is between $30 \mathrm{~g} / \mathrm{L}$ (Nieva-Echevarría et al. 2016), so $0.3 \%$ is considered a critical level for checking the bile tolerance ability of isolates by in vitro condition. B. cereus and $B$. thuringiensis screened in the present study showed increased survival after $3 \mathrm{~h}$ exposure to bile salt condition $(0.3$ and $1 \%)$ indicating their bile tolerance. Moreover, the two isolates showed stronger bile tolerance than other probiotics reported by earlier studies Lactobacillus sp. (Shehata et al. 2016), Enterococcus faecium (Rehaiem et al. 2014) and Bacillus sp. (Thankappan et al. 2015). The two Bacillus sp. also exhibited high BSH activity by producing large precipitation zones ( 7.2 and $6.8 \mathrm{~mm}$ respectively) in bile salt medium. The current result supports that the BSH activity of probiotics renders them more resistant to bile salt (Noriega et al. 2006). Overall, B. cereus KAF124 and B. thuringiensis KAF135 showed a high capacity of gastrointestinal transit tolerance, and these results are significant for considering these isolates as a potential candidate for probiotics development in the aquaculture sector.

Hydrophobicity is another key factor that contributes to the adhesion properties to the host tissues (Guo et al. 2010) and the most commonly accepted way to identify non-specific cell adhesion properties (Rijnaarts et al. 1993). Consequently, this could indicate a key feature of the bacterial balance in the fish gut and contribute to the competitive exclusion of pathogens (Gueimonde and Salminen 2006). The in vitro measurement of adhesion property has been extensively studied using various hydrocarbons. Herein, the results suggested that $B$. thuringiensis cell wall (KAF135) may be highly hydrophobic in nature and have acidic characteristics. Moreover, the same isolate (KAF135) had maximum autoaggregation ability (75\%) after $2 \mathrm{~h}$ incubation; illustrating aggregation is related to surface hydrophobicity (Del Re et al. 2000). This result is correlated with previous studies reported for Propionibacterium freudenreichii subsp. Shermanii (Zárate et al. 2002), Propionibacterium sp. (Darlimaz et al. 2012), Lactobacillus salivaris and Bacillus breve (Collado et al. 2008). The attribute of autoaggregation appears to be an essential probiotic feature for adhering to the intestinal epithelial cells, along with co-aggregation posing a barrier that prevents pathogenic colonization in the gut region (Del Re et al. 2000). Here, KAF135 and 124 showed remarkable co-aggregation ability with all the three pathogens tested with varying percentages. These results support that the co-aggregation ability directly correlates with auto aggregation propensity.

The ability of probiotics to exert antioxidant activity has been attracted since the reduction of excessive reactive radicals contributes to the prevention and control of several diseases associated with oxidative stress in aquaculture organisms. Among the four probiotics, KAF135 (B. thuringiensis) showed higher activity in DPPH, ABTS, radical scavenging, and $\beta$-carotene bleaching inhibition indicating their antioxidant potential. Overall results indicated that the B. thuringiensis possessed comparable antioxidant activity than Lactobacillus plantarum Ln1 (Jang et al. 2018), L. plantarum B4496 (Das and Goyal 2015) and Leuconostoc sp. (Ji et al. 2015) evaluated in earlier reports.

The ability of probiotics to produce extracellular enzymes such as protease, amylase, and cellulase are another anticipated property to select the potential probiotics, since these enzymes play a major role in the feed utility, feed conversion ratio (Mulyasari et al. 2016) and reducing environmental pollution (Lalloo et al. 2007). The in vitro results of the current study strongly confirm that the characterized two Bacillus sp. are potential candidates to use as probiotics when compared to the Pseudomonas sp.

The probiotic supplemented diet was found to be safe as there were no mortalities observed during the study period of 30 days, indicating the non-pathogenic nature of probiotics and enhancing non-specific immunity. On the other hand, all the fish died in the pathogen treated control group indicating the protective role of probiotics against microbial infection. This current safety experiment result was supported by Wang et al. (2020) and Dias et al. (2018) who tested $B$. cereus and reported that the strain was safe to $O$. niloticus and Colossoma macropomum respectively and improved their growth.

The hematological analysis is evidenced by a significant increase in all the blood parameters in the group fed with KAF124, 135 and commercial probiotic when compared to the control group. The current result was supported by Abomughaid (2020) and Aly et al. (2008). All these reports revealed that nonspecific immunity was more intensely stimulated by tested probiotics, KAF124 and 135 than positive control, B. subtilis.

\section{Conclusion}

The two Bacillus strains, B. cereus KAF124 and B. thuringiensis KAF135 showed better probiotic attributes including broad spectrum of antimicrobial activity, biosafety, possible transit and colonize in the gastrointestinal tract, capacity to produce various essential digestive enzymes with antioxidant potential than that of the commercial probiotic, B. subtilis. Further, these two isolates were proved as nonpathogenic and they stimulated fish growth and nonspecific immunity better than B. subtilis. The results concluded that the two Bacillus sp. KAF124 and 135 could be better probiotic candidates than that of commercial probiotic, $B$. subtilis. The study also reveals that the in vitro screening of native probiotics from marine sources constitutes a valuable approach for the large-scale preliminary selection of most effective and safe probiotics anticipated for enhancing the aquaculture production. 
Funding This research article was financially supported by UGC, India (F.15-1/2016-17/PDFWM-2015-17-TAM-36709/ SA-II), Bharathidasan University, DST-PURSE-II \& RUSA 2.0 Biological Sciences) in the form of UGC-women post-doctoral fellowship to DS, URF to FH and research grant to the corresponding author (KA) respectively.

Data availability The isolates are available in the Microbial Biotechnology laboratory for scientific research use.

\section{Declarations}

Informed consent statement Not applicable.

Conflict of interests Authors declare no conflict of interests.

\section{References}

Abatenh E, Gizaw B, Tsegay Z, Tefera G, Aynalem E (2018) Health benefits of probiotics. J Bacteriol Infec Dis 2(1).

Abomughaid MM (2020) Isolation and identification of some probiotic Bacteria and their potential role in improving immune response and resistance of Nile Tilapia (Oreochromis niloticus) in comparison with a commercial product. IntJ Microbiol 2020. https://doi. org/10.1155/2020/8865456

Anbarasu K, Chandran MR (2001) Effect of ascorbic acid on the immune response of the catfish, Mystus gulio (Hamilton), to different bacterins of Aeromonas hydrophila. Fish Shellfish Immunol. 11:347-355. https://doi.org/10.1006/fsim.2000.0322

Anbarasu K, Thangakrishnan K, Aruna BV, Chandran MR (1998) Assessment of immune response in freshwater catfish Mystus vittatus (Bloch) to different bacterins of Aeromonas hydrophila. Indian J Exp Biol 36:990-995

Austin B. 2015. Aeromonas fish pathogens. Aeromonas . 45-64. https://doi.org/10.21775/9781908230560.03

Austin B, Austin DA (2012). Miscellaneous Pathogens. pp. 413-441. Bacterial Fish Pathogens, Springer, https://doi.org/10.1007/ 978-94-007-4884-2_7

Bachere E (2000) Shrimp immunity and disease control. Aquaculture. 191:3-11. https://doi.org/10.1016/S0044-8486(00)00413-0

Chauhan A, Singh R (2019) Probiotics in aquaculture: a promising emerging alternative approach. Symbiosis. 77:99-113. https://doi. org/10.1007/s13199-018-0580-1

Collado MC, Meriluoto J, Salminen S (2008) Adhesion and aggregation properties of probiotic and pathogen strains. Eur Food Res Technol 226:1065-1073. https://doi.org/10.1007/s00217-007-0632-x

Darilmaz DO, Beyatli Y, Yuksekdag ZN (2012) Aggregation and hydrophobicity properties of 6 dairy Propionibacteria strains isolated from homemade Turkish cheeses. J Food Sci 77:M20-M24. https://doi.org/10.1111/j.1750-3841.2011.02438.x

Das D, Goyal A (2015) Antioxidant activity and $\gamma$-aminobutyric acid (GABA) producing ability of probiotic Lactobacillus plantarum DM5 isolated from Marcha of Sikkim. LWT - Food Sci Technol 61:263-268. https://doi.org/10.1016/j.lwt.2014.11.013

de Azevedo RV, Filho JCF, Cardoso LD, da Cruz Mattos D, Júnior MVV, de Andrade DR (2015) Economic evaluation of prebiotics, probiotics and symbiotics in juvenile Nile tilapia. Rev Cienc Agron 46:72-79. https://doi.org/10.1590/s1806-6690201500 0100009

Del Re B, Sgorbati B, Miglioli M, Palenzona D (2000) Adhesion, autoaggregation and hydrophobicity of 13 strains of Bifidobacterium longum. Lett Appl Microbiol 31:438-442. https://doi. org/10.1046/j.1365-2672.2000.00845.x
Dias JA, Abe HA, Sousa NC, Couto MV, Cordeiro CA, Meneses JO, Cunha FS, Mouriño JL, Martins ML, Barbas LA, Carneiro PC (2018) Dietary supplementation with autochthonous Bacillus cereus improves growth performance and survival in tambaqui Colossoma macropomum. Aquac Res 49(9):3063-3070. https:// doi.org/10.1111/are.13767

Ghosh S, Sinha A, Sahu C (2007) Effect of probiotic on reproductive performance in female livebearing ornamental fish. Aquac Res 38:518-526. https://doi.org/10.1111/j.1365-2109.2007.01696.x

Gobi N, Vaseeharan B, Chen JC, Rekha R, Vijayakumar S, Anjugam M, Iswarya A (2018) Dietary supplementation of probiotic Bacillus licheniformis Dahb1 improves growth performance, mucus and serum immune parameters, antioxidant enzyme activity as well as resistance against Aeromonas hydrophila in tilapia Oreochromis mossambicus. Fish Shellfish Immunol. 74:501-508. https://doi.org/10.1016/j.fsi.2017.12.066

Gohil K, Samson R, Dastager S, Dharne M (2021) Probiotics in the prophylaxis of COVID-19: something is better than nothing. 3 . Biotech. 11:1. https://doi.org/10.1007/s13205-020-02554-1

Gueimonde M, Salminen S (2006) New methods for selecting and evaluating probiotics. Dig Liver Dis 38:S242-S247. https://doi. org/10.1016/S1590-8658(07)60003-6

Guo XH, Kim JM, Nam HM, Park SY, Kim JM (2010) Screening lactic acid bacteria from swine origins for multistrain probiotics based on in vitro functional properties. Anaerobe. 16:321-326. https:// doi.org/10.1016/j.anaerobe.2010.03.006

Hai NV (2015) The use of probiotics in aquaculture. J Appl Microbiol 119:917-935. https://doi.org/10.1111/jam.12886

Hong HA, Le HD, Cutting SM (2005) The use of bacterial spore formers as probiotics. FEMS Microbiol Rev 29:813-835. https://doi. org/10.1016/j.femsre.2004.12.001

Hoque F, Jawahar AT, Nagesh TS, Kamilya D (2019) Pseudomonas aeruginosa FARP72 offers protection against Aeromonas hydrophila infection in Labeo rohita. Probiotics Antimicrob Proteins 11:973-980. https://doi.org/10.1007/s12602-018-9456-1

Hoseinifar SH, Sun YZ, Caipang CM (2017) Short-chain fatty acids as feed supplements for sustainable aquaculture: an updated view. Aquac Res 48:1380-1391. https://doi.org/10.1111/are.13239

Jadhav HP, Shaikh SS, Sayyed RZ (2017) Role of hydrolytic enzymes of Rhizoflora in biocontrol of fungal Phytopathogens: an overview. In: Mehnaz S (ed) Rhizotrophs: plant growth promotion to bioremediation, Springer Singapore, Singapore, pp 183-203. https://doi.org/10.1007/978-981-10-4862-3_9

Jang HJ, Song MW, Lee NK, Paik HD (2018) Antioxidant effects of live and heat-killed probiotic Lactobacillus plantarum Ln1 isolated from kimchi. J Food Sci Technol 55:3174-3180. https://doi. org/10.1007/s13197-018-3245-4

Jayashree S, Pooja S, Pushpanathan M, Rajendhran J, Gunasekaran P (2014) Identification and characterization of bile salt hydrolase genes from the genome of Lactobacillus fermentum MTCC 8711. Appl Biochem Biotechnol 174:855-866. https://doi.org/10.1007/ s12010-014-1118-5

Ji K, Jang NY, Kim YT (2015) Isolation of lactic acid bacteria showing antioxidative and probiotic activities from kimchi and infant feces. J Microbiol Biotechnol 25:1568-1577. https://doi.org/10. 4014/jmb.1501.01077

Kolndadacha OD, Adikwu IA, Okaeme AN, Atiribom RY, Mohammed A, Musa YM (2011) The role of probiotics in aquaculture in Nigeria-a review. Cont J Fish Aquat Sci 5:8-15

Kumar S, Stecher G, Li M, Knyaz C, Tamura K (2018) MEGA X: molecular evolutionary genetics analysis across computing platforms. Mol Biol Evol 35:1547-1549. https://doi.org/10.1093/ molbev/msy096

Lalloo R, Ramchuran S, Ramduth D, Görgens J, Gardiner N (2007) Isolation and selection of Bacillus spp. as potential biological agents for enhancement of water quality in culture of ornamental 
fish. J Appl Microbiol 103:1471-1479. https://doi.org/10.1111/j. 1365-2672.2007.03360.x

Lara-Flores M, Olvera-Novoa MA (2013) The use of lactic acid bacteria isolated from intestinal tract of Nile tilapia (Oreochromis niloticus), as growth promoters in fish fed low protein diets. Lat Am J Aquat Res 41:490-497. https://doi.org/10.3856/vol41issue3-fulltext-12

Li L, Boyd CE, Sun Z (2016) Authentication of fishery and aquaculture products by multi-element and stable isotope analysis. Food Chem 194:1238-1244. https://doi.org/10.1016/j.foodchem.2015.08.123

Loh J (2017) The role of probiotics and their mechanisms of action: an aquaculture perspective. World Aquac 48:19-23

Ma CW, Cho YS, Oh KH (2009) Removal of pathogenic bacteria and nitrogens by Lactobacillus spp. JK-8 and JK-11. Aquaculture. 287:266-270. https://doi.org/10.1016/j.aquaculture.2008.10.061

Martínez CP, Ibáñez AL, Monroy Hermosillo OA, Ramírez Saad HC (2012) Use of probiotics in aquaculture. ISRN Microbiol 2012:113. https://doi.org/10.5402/2012/916845

Mazza P (1994) The use of Bacillus subtilis as an antidiarrhoeal microorganism. Boll Chim Farm 133:3-18

Meidong R, Khotchanalekha K, Doolgindachbaporn S, Nagasawa T, Nakao M, Sakai K, Tongpim S (2018) Evaluation of probiotic Bacillus aerius B81e isolated from healthy hybrid catfish on growth, disease resistance and innate immunity of Pla-mong Pangasius bocourti. Fish Shellfish Immunol. 73:1-10. https://doi. org/10.1016/j.fsi.2017.11.032

Mo WY, Man YB, Wong MH (2018) Use of food waste, fish waste and food processing waste for China's aquaculture industry: needs and challenge. Sci Total Environ 613-614:635-643. https://doi.org/10. 1016/j.scitotenv.2017.08.321

Mulyasari W, Suprayudi MA, Zairin M, Sunarno MTD (2016) Screening of probiotics from the digestive tract of gouramy (Osphronemus goramy) and their potency to enhance the growth of tilapia (Oreochromis niloticus). AACL Bioflux 9:1121-1132

Muthukumar P, Kandeepan C (2015) Isolation, identification and characterization of probiotic organisms from intestine of fresh water fishes. Int J Curr Microbiol Appl Sci 4:607-616

Nandi A, Banerjee G, Dan SK, Ghosh K, Ray AK (2017) Probiotic efficiency of Bacillus sp. in Labeo rohita challenged by Aeromonas hydrophila: assessment of stress profile, haemato-biochemical parameters and immune responses. Aquac Res 48:4334-4345. https://doi.org/10.1111/are.13255

Nayak SK (2010) Probiotics and immunity: a fish perspective. Fish Shellfish Immunol 29:2-14. https://doi.org/10.1016/j.fsi.2010. 02.017

Newaj-Fyzul A, Al-Harbi AH, Austin B (2014) Review: developments in the use of probiotics for disease control in aquaculture. Aquaculture. 431:1-11. https://doi.org/10.1016/j.aquaculture.2013.08. 026

Nieva-Echevarría B, Goicoechea E, Manzanos MJ, Guillén MD (2016) A study by $1 \mathrm{H}$ NMR on the influence of some factors affecting lipid in vitro digestion. Food Chem 211:17-26. https://doi.org/10. 1016/j.foodchem.2016.05.021

Noriega L, Cuevas I, Margolles A, de los Reyes-Gavilán CG (2006) Deconjugation and bile salts hydrolase activity by Bifidobacterium strains with acquired resistance to bile. Int Dairy J 16:850-855. https://doi.org/10.1016/j.idairyj.2005.09.008

Patil PK, Geetha R, Ravisankar T, Avunje S, Solanki HG, Abraham TJ, Vinoth SP, Jithendran KP, Alavandi SV, Vijayan KK (2021) Economic loss due to diseases in Indian shrimp farming with special reference to Enterocytozoon hepatopenaei (EHP) and white spot syndrome virus (WSSV). Aquaculture 533:736231. https://doi. org/10.1016/j.aquaculture.2020.736231

Perin LM, Miranda RO, Todorov SD, de Melo Franco BDG, Nero LA (2014) Virulence, antibiotic resistance and biogenic amines of bacteriocinogenic lactococci and enterococci isolated from goat milk. Int J Food Microbiol 185:121-126. https://doi.org/ 10.1016/j.ijfoodmicro.2014.06.001

Pinchuk IV, Bressollier P, Verneuil B, Fenet B, Sorokulova IB, Mégraud F, Urdaci MC (2001) In vitro anti-helicobacter pylori activity of the probiotic strain Bacillus subtilis 3 is due to secretion of antibiotics. Antimicrob Agents Chemother 45:31563161. https://doi.org/10.1128/AAC.45.11.3156-3161.2001

Rehaiem A, Belgacem Z, Ben EMR, Martínez B, Rodríguez A, Manai M, Guerra NP (2014) Assessment of potential probiotic properties and multiple bacteriocin encoding-genes of the technological performing strain Enterococcus faecium MMRA. Food Control 37:343-350. https://doi.org/10.1016/j.foodcont. 2013.09.044

Rijnaarts HHM, Norde W, Bouwer EJ, Lyklema J, Zehnder AJB (1993) Bacterial adhesion under static and dynamic conditions. Appl Environ Microbiol 59:3255-3265. https://doi.org/10.1128/ aem.59.10.3255-3265.1993

Rosenberg M, Gutnick D, Rosenberg E (1980) Adherence of bacteria to hydrocarbons: a simple method for measuring cell-surface hydrophobicity. FEMS Microbiol Lett 9:29-33. https://doi.org/ 10.1111/j.1574-6968.1980.tb05599.x

Shehata MG, El Sohaimy SA, El-Sahn MA, Youssef MM (2016) Screening of isolated potential probiotic lactic acid bacteria for cholesterol lowering property and bile salt hydrolase activity. Ann Agric Sci 61:65-75. https://doi.org/10.1016/j.aoas.2016. 03.001

Shen Q, Zhang B, Xu R, Wang Y, Ding X, Li P (2010) Antioxidant activity in vitro of the selenium-contained protein from the seenriched Bifidobacterium animalis 01. Anaerobe. 16:380-386. https://doi.org/10.1016/j.anaerobe.2010.06.006

Stein T (2005) Bacillus subtilis antibiotics: structures, syntheses and specific functions. Mol Microbiol 56:845-857. https://doi.org/ 10.1111/j.1365-2958.2005.04587.x

Tachibana L, Telli GS, de Carla Dias D, Gonçalves GS, Ishikawa CM, Cavalcante RB, Natori MM, Hamed SB, Jose TM, Ranzani-Paiva MJT (2020) Effect of feeding strategy of probiotic Enterococcus faecium on growth performance, hzzematologic, biochemical parameters and non-specific immune response of Nile tilapia. Aquaculture Reports 16:100277. https://doi.org/10.1016/j.aqrep.2020.100277

Thankappan B, Ramesh D, Ramkumar S, Natarajaseenivasan K, Anbarasu K (2015) Characterization of Bacillus spp. from the gastrointestinal tract of Labeo rohita-towards to identify novel probiotics against. Fish Pathogens Appl Biochem Biotechnol 175:340-353. https://doi.org/10.1007/s12010-014-1270-y

Urdaci MC, Pinchuk IV (2004) Antimicrobial activity of Bacillus probiotics. Bact Spore Formers Probiotics Emerg Appl:171-182

Valeriano VD, Parungao-Balolong MM, Kang DK (2014) In vitro evaluation of the mucin-adhesion ability and probiotic potential of Lactobacillus mucosae LM1. J Appl Microbiol 117:485-497. https://doi.org/10.1111/jam.12539

Vijayan KK, Kumar S, Alavandi SV (2017) Emerging pathogens in brackish aquaculture and challenges in aquatic health management. In: Proceddings of international symposium on aquatic animal health and epidemiology for sustainable Asian aquaculture, April 20-21, 2017. ICAR-National Bureau of fish genetic resources, Lucknow, pp 140-144

Wang M, Yi M, Lu M, Gao F, Liu Z, Huang Q, Li Q, Zhu D (2020) Effects of probiotics Bacillus cereus NY5 and Alcaligenes faecalis $\mathrm{Y} 311$ used as water additives on the microbiota and immune enzyme activities in three mucosal tissues in Nile tilapia Oreochromis niloticus reared in outdoor tanks. Aquaculture Reports 17:100309. https://doi.org/10.1016/j.aqrep.2020.100309

Wanka KM, Damerau T, Costas B, Krueger A, Schulz C, Wuertz S (2018) Isolation and characterization of native probiotics for fish farming. BMC Microbiol 18:119. https://doi.org/10.1186/ s12866-018-1260-2 
Widanarni W., Yuhana M. \& Muhammad A. 2015. Bacillus NP5 improves growth performance and resistance against infectious Myonecrosis virus in white shrimp (Litopenaeus vannamei) (Bacillus NP5 Meningkatkan Pertumbuhan dan Ketahanan Terhadap Infeksi virus Myonecrosis pada Udang Putih (L. vannamei). ILMU Kelaut. Indones. J Mar Sci 19: 211. https://doi.org/10.1186/ s12866-018-1260-2

Zárate G, De Ambrosini VIM, Perez CA, González SN (2002) Adhesion of dairy Propionibacteria to intestinal epithelial tissue in vitro and in vivo. J Food Prot 65:534-539. https://doi.org/10.4315/ 0362-028X-65.3.534
Zheng M, Zhang R, Tian X, Zhou X, Pan X, Wong A (2017) Assessing the risk of probiotic dietary supplements in the context of antibiotic resistance. Front Microbiol 8:908. https://doi.org/10. 3389/fmicb.2017.00908

Publisher's note Springer Nature remains neutral with regard to jurisdictional claims in published maps and institutional affiliations. 